(1) norden

\title{
Measuring green jobs?
}

An evaluation of definitions and statistics for green activities

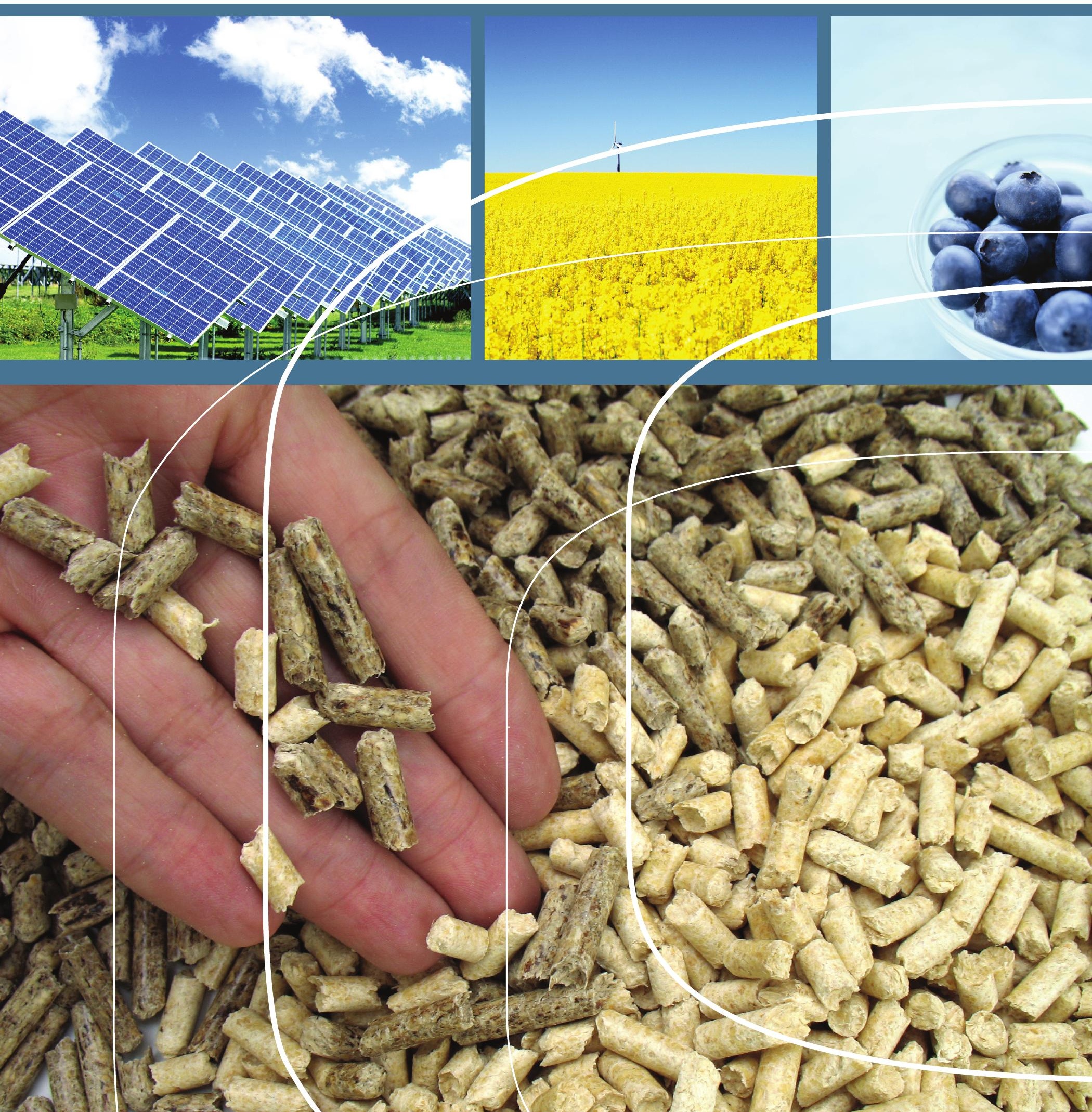



4 norden 



\section{Measuring green jobs?}

An evaluation of definitions and statistics for green activities

Annegrete Bruvoll and Karin Ibenholt (ed.), Sanna Ahvenharju, Marika Bröckl, Louise Martinsen and Marianne Zandersen 
Measuring green jobs?

An evaluation of definitions and statistics for green activities Annegrete Bruvoll and Karin Ibenholt (ed.), Sanna Ahvenharju, Marika Bröckl, Louise Martinsen and Marianne Zandersen

TemaNord 2012:534

ISBN 978-92-893-2370-3

http://dx.doi.org/10.6027/TN2012534

(c) Nordic Council of Ministers 2012

Cover photo: Photodisc; ImageSelect

Print: Kailow Express ApS

Copies: 260

Printed in Denmark

This publication has been published with financial support by the Nordic Council of Ministers. However, the contents of this publication do not necessarily reflect the views, policies or recommendations of the Nordic Council of Ministers.

\section{www.norden.org/en/publications}

\section{Nordic co-operation}

Nordic co-operation is one of the world's most extensive forms of regional collaboration, involving Denmark, Finland, Iceland, Norway, Sweden, and the Faroe Islands, Greenland, and Åland.

Nordic co-operation has firm traditions in politics, the economy, and culture. It plays an important role in European and international collaboration, and aims at creating a strong Nordic community in a strong Europe.

Nordic co-operation seeks to safeguard Nordic and regional interests and principles in the global community. Common Nordic values help the region solidify its position as one of the world's most innovative and competitive.

\section{Nordic Council of Ministers}

Ved Stranden 18

DK-1061 Copenhagen $\mathrm{K}$

Phone (+45) 33960200

\section{www.norden.org}




\section{Content}

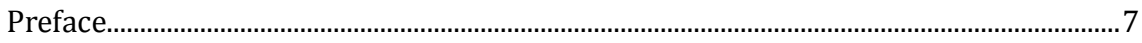

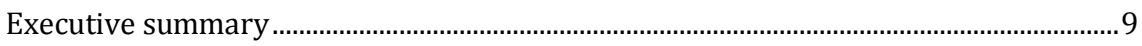

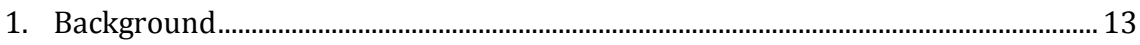

2. Definitions of green sectors ................................................................................ 15

2.1 United Nations and Eurostat: Environmental Goods and Services Sector (EGSS) ..................................................................................................... 15

2.2 US Bureau of Labour Statistics........................................................................ 18

2.3 The Green Jobs Initiative - UNEP, ILO, ITUC.................................................. 20

2.4 Metropolitan Policy Program ................................................................................... 21

3. Evaluation of the statistical frameworks.................................................................. 23

3.1 The intentions of the statistics...................................................................... 23

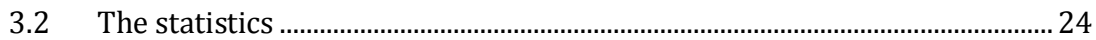

3.3 Do the statistics match the intentions?........................................................... 25

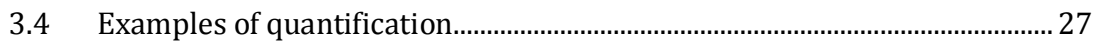

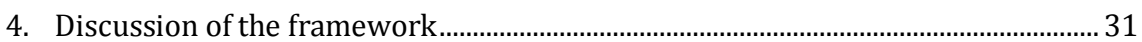

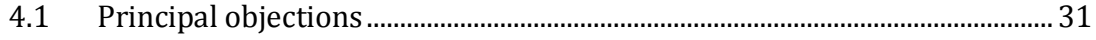

4.2 Specific comments to the EGSS framework ....................................................... 33

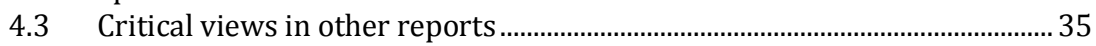

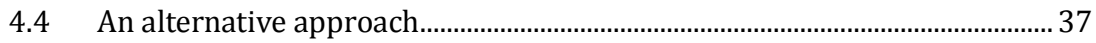

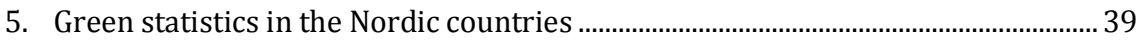

5.1 Denmark 39

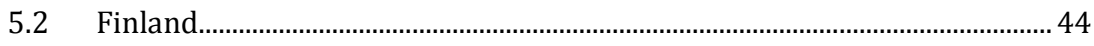

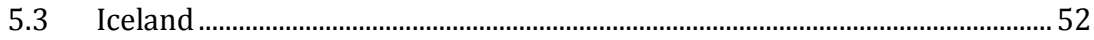

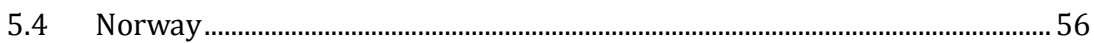

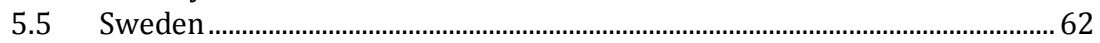

6. Future production and employment pattern............................................................ 65

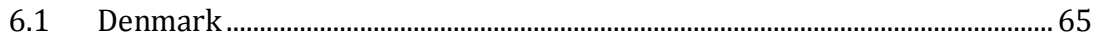

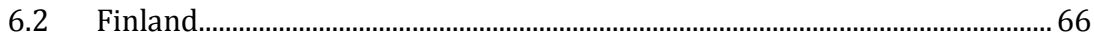

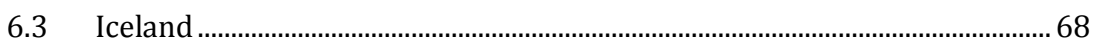

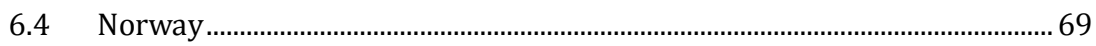

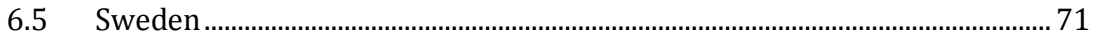

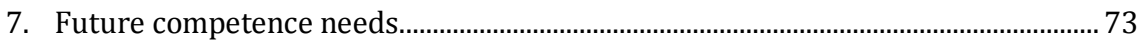

7.1 Denmark: Competence trends and mismatch................................................. 74

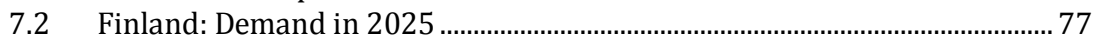

7.3 Norway: Demand and supply by education ..................................................... 80

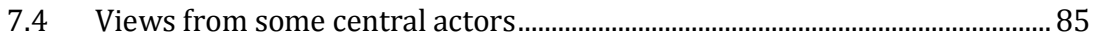

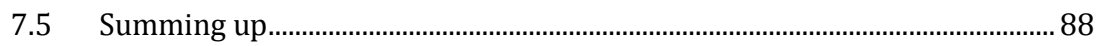

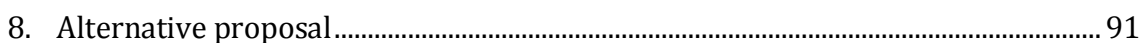

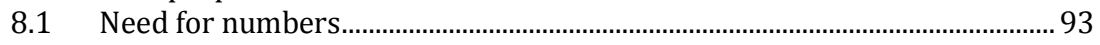

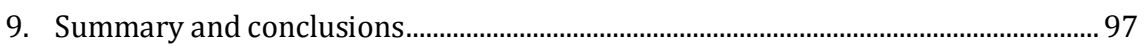

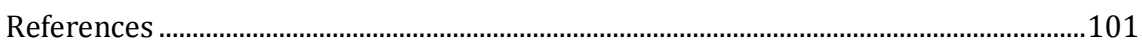

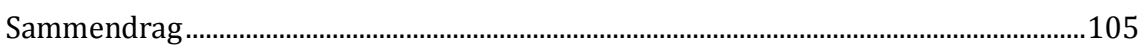





\section{Preface}

In discussing and planning for greener growth, a fundamental question is how to measure, compare and keep track of how "green" companies, sectors and countries are, and how the results of green growth policies can be accounted for and evaluated.

A particular focus of the discussion of such issues is on the number of "green" jobs and companies, and, from this, on the share of a country's employment, GDP (gross domestic product) and exports in such companies and sectors. In recent years, several efforts, national and international, have been made to establish a sound statistical basis for such accounting. This report was commissioned by the Working Group on Environment and Economy of the Nordic Council of Ministers to evaluate such efforts and to provide advice on how best to keep track of how "green" (or "environmentally friendly") economic sectors are and how they and the overall economy develop.

The report argues that it is both theoretically and practically extremely challenging if not outright impossible to measure, define and delineate which jobs, companies and sectors that are "green", while other jobs, companies and sectors are not. This is partly because all production (and consumption) of goods and services have environmental effects, and "greenness" must be a relative concept, and partly because all jobs and companies are just part of long production and delivery chains involving many companies and sectors, "green" and non-green.

The report also argues that the core issue of green growth is not the relative size of "green" sectors, but the aggregate environmental impacts of the whole economy. The need to track both overall developments and the environmental effects and performance of individual economic sectors can be met by further developing existing statistics and data, linking economic data from national accounting with emission data and other environmental statistics for all economic sectors, not just "green" sectors. The UN System of Environmental-Economic Accounts (SEEA) and, in particular, the European NAMEA system (National Accounting Matrix including Environmental Accounts), applied in several Nordic countries, provide a framework for using and further developing such data, and can also be used for linking to macro-economic modeling and analysis of highly relevant environmental policy issues, 
Because "green" jobs and employment are difficult to define in any meaningful way, education and labour qualification requirements are also difficult to identify very precisely. One conclusion might be that a generally higher education and competence level is useful for green growth, even if new environmentally friendly technologies can provide both low- and high-skilled jobs. Technical, engineering, design and marketing skills are often required for such new technologies, but, overall, the need is for environmental-improvement skills in all sectors and at all educational levels.

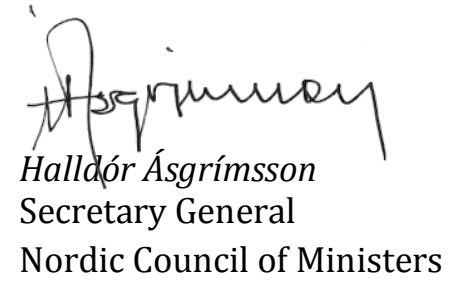




\section{Executive summary}

Several international initiatives have been made to produce statistics on "green" activities, such as green sectors, jobs and technologies, among them the UN and the Eurostat as the core institutions. Environmental authorities and policy makers ask for information to perform international comparisons, to track environmental progress in sectors and the economy as a whole and to demonstrate the effects of environmental policies. Countries with high unemployment seek new business opportunities to stimulate employment and economic growth.

The logical implication of statistics on green activities, is that the economic activities are separated in two groups; green, and, consequently, non-green activities. We conclude that it is not theoretically possible to consistently delineate green activities from the rest of the economy. The reason is that all activities bring along some level of environmental pressure, and are hence more or less green. Sectors typically categorized as green, e.g. renewable energy, imply severe damages on nature, although being less emission intensive than fossil fuel energy production. Gas power plants, on the other hand, are not labelled as green. They imply carbon emissions, but do not inflict pristine areas, biodiversity, and gas power contributes to lower emissions than other fossil fuels.

Further, in a welfare perspective, production, emissions and employment must balance to provide the desired bundles of goods and services. While some sectors face significantly higher emissions per produced units and per employed workers than others, the interdependency between activities makes it problematic to credit some particular sectors as being more environmentally friendly than others.

The UN/Eurostat initiative (planned to become the international standard) includes activities with an environmental purpose (environmental protection or resource management purpose) as the prime objective. In principle, no activity has environment as its prime objective. The purpose of e.g. hydro power plants is to make profit, just as for other businesses. All activities involve a set of environmental consequences, some negative and some positive. Whether the prime objective of an activity is environmental or not, is a matter of subjective considerations, and not an absolute. It is thus not possible to make mutually exclusive categories for which activities that have an environmental purpose, and, 
which are green and non-green. Rather than making two categories, there is a continuous range of environmental damages per produced unit or per employed worker.

By defining some activities as green and others as not-green - let us again use hydro and gas power production as examples - the producer of the statistics has made subjective evaluations of the total environmental costs. The implication is that the sum of lost recreational values, methane emissions costs, reduced biodiversity and other costs related to hydro-power dams is lower than the carbon emission and other costs related to gas power production.

Implicitly, such evaluations underlie all categorization of green sectors, technologies and jobs. The categorization hence implies valuation of environmental externalities, without explicitly confronting the valuation criteria.

Due to the lack of principal foundation, the categorization relies on normative and not methodologically consistent nor transparent judgments made by the producers of the statistics. Our main conclusion is that the green sector initiatives imply production of data with poor statistical quality.

The demand for green activity data is driven by the need for international comparisons, and to track progress on environmental progress in different sectors and the economy as a whole. Environmental authorities and politicians ask for information to demonstrate the effects of environmental policies. Countries with high unemployment seek new business opportunities and additional jobs for economic growth.

The use of conventional statistics covers all these information needs. Conventional statistics offer transparent and interpretable factual data on emissions, resource, employment and production, and enable measurements of environmental load and related employment per sector without creating normative categories for which activities are green and non-green. The statistics combine environmental and economic data suitable for policy analyses. A consistent way to use the statistics could be to calculate the environmental damages per produced unit of different sectors and track the development over time. This can be done by using traditional statistical methods and data. Emissions and other damages may be weighed together using cost estimates from the literature, to form estimates or uncertainty intervals for the more overall environmental pressure, if such information is requested. Finally, economic models offer forecasts for potential economic and environmental development, and hence the need for environmental instruments and policy to stimulate relevant competence development. 
Green growth is not about green or not-green sectors, but about whether the economy as a whole develops in a more environmentally friendly direction given their relative starting points. An economically efficient and consistent way to reach environmental targets is to use general instruments securing equal marginal abatement costs across sectors. Such instruments comprise environmental changes from taxes and cap and trade systems and general regulations securing cost efficient emission reductions and nature preservation.

The report further looks at present and future economic structures and needs for labour to meet environmental challenges. As a general trend in the Nordic countries, jobs are getting more knowledge intensive. This does not necessarily correlate to environmentally friendly technologies, since these require both low and high skilled jobs. The main educational fields required by sectors often categorized as green are technical and engineering, in addition to marketing skills. Higher competence levels may increase the general knowledge level, including environmental consequences, and contribute to more efficient production processes. This implies a lower use of material and energy input, and hence lower environmental pressure. Environmental policies will influence relative competitiveness of different sectors and hence the demand for educated labour. From a policy point of view it is difficult to point out specifically which types of education will be most important to support in the future in an environmental perspective. 



\section{Background}

A transition to a future with lower greenhouse gas emissions and other environmental damages in the Nordic countries as well as in the rest of the world in the coming decades, calls for a greening of the economy, i.e. more environmentally friendly production processes and technologies. Education will be important to increase environmental awareness and resource efficient innovation.

As a response to the need for information helping us to understand the transition to a greener economy several initiatives have been made to measure "green sectors", "green jobs" and "green technologies". The motivation seems to be need for insight into I) the environmental state and the potential for environmentally friendly activities, and the policy responses to II) the environment, III) employment and other economic factors. There are no principal unambiguous criteria for distinguishing between "green" and "non-green" jobs, technologies and activities, and consequently, there is no commonly agreed definition across the different initiatives made to measure the green factors. Hence, there is a need to clarify and structure relevant concepts to improve the information asked for.

This report reviews initiatives made to measure these aspects, discusses whether the statistics collected under the present initiatives increase insights into the fundamental questions motivating the initiatives, and looks into information on future economic structures and needs for educated labour to meet environmental challenges. Suggestions are made on which data would be best suited for producing the relevant information.

The main international initiative is the UN/ Eurostat Environmental Goods and Services Sector (EGSS), which is planned to be incorporated in the UN accounting system. Several other national initiatives focus on "green jobs", "clean economy" and "cleantech companies", e.g. the US Bureau of Labour Statistics initiative. The report particularly emphasizes the UN/Eurostat framework, since this is planned as the international statistical standard, and the Nordic perspective. 



\section{Definitions of green sectors}

This chapter presents and discusses the main initiatives made to measure the green aspects. The main initiative is the UN/Eurostat definition of the Environmental Goods and Services Sector (EGSS). The EGSS is planned to be incorporated in the UN System of Integrated Environmental-Economic Accounting (SEEA), and to become the international statistical standard from 2012 onwards. We also emphasise the US Bureau of Labor Statistics measurements of Green jobs, since this initiative is rather specific regarding the included statistics and particularly emphasizes the employment aspect. Also, we look into the joint initiative by United Nations Environment Programme, the International Labor Organization and the International Trade Union Confederation in measuring Green jobs, and the Metropolitan Policy Program measurements of the US Clean economy.

\subsection{United Nations and Eurostat: Environmental Goods and Services Sector (EGSS)}

Main sources: UN (2011), Eurostat (2009).

The Eurostat and UN framework Environmental Goods and Services Sector (EGSS) proposes a method for identifying environmental activities, i.e. "those economic activities whose primary purpose is to reduce or eliminate pressures on the environment or to make more efficient use of natural resources" (UN 2011; 1.110).

The EGSS considers environmental activities from the supply perspective and EGSS statistics aim to present information on the production of environmental goods and services in as much detail as possible. The statistics include indicators of the production of environmental goods, services and technologies and the extent of related employment, investment and exports from the sector (UN 2011; 4.93). 


\subsubsection{Intention}

The stated intention is to "provide an information base to assess the potential for economic activity and employment to be based on environmentally friendly and more resource efficient activities and to assess the extent to which the economy is responding to various public policies and initiatives that have this objective in mind." (UN 2011, p. 141). The statistics should increase the understanding of the economic response to the challenges of environmental degradation and depletion of natural resources and provide information on the extent to which the economy may become more environmentally friendly and resource efficient. Another intention is to define the statistics in an internationally comparable way to permit cross-country comparison and assessment of best practice (UN 2011; 4.94).

The motive for focussing on green jobs is not explicitly expressed in the documents. A motive is probably that structural changes due a cleaner economy can provide new business opportunities and additional employment and economic growth. E.g. the UN expresses "Employment information such as the number of people employed, the number of jobs and the number of hours worked may be of particular interest in the assessment of environmental activity from an industry perspective. In particular, there is likely to be interest in employment indicators related to the production of environmental goods and services." (UN 2011; 2.75), and Eurostat (2009) claims that the statistics can help to answer the potential for job creation (p. 25).

\subsubsection{Specification of statistics}

The statistics on the Environmental Goods and Services Sector (EGSS) comprise "economic transactions within the core SNA that may be considered environmental. Of particular interest are those transactions that relate to environmental activities, i.e. those economic activities whose primary purpose is to reduce or eliminate pressures on the environment or to make more efficient use of natural resources" (UN 2011; 1.110); i.e. "products that can be identified as being specifically produced, designed, and manufactured for purposes of environmental protection and resource management" (UN 2011; 4.96). Focus has been on the variables that give an indication of the relative economic size and contribution of EGSS, i.e. the output, value added, employment, exports, and gross fixed capital formation related to the production of environmental goods and services.

The following environmental goods and services are in scope of the EGSS (UN 2011; 4.97-4.105): 
1. Environmental specific services: environmental protection and resource management services produced by economic units for sale or own-use. Those services that have the main purpose of:

a) preventing or minimising pollution, degradation, or natural resources depletion (including the production of energy from renewable sources) (S1) ${ }^{1}$

b) treating and managing pollution, degradation, and natural resource depletion (S2)

c) repairing damage to air, soil, water, biodiversity, and landscapes (S3)

d) carrying out other activities such as measurement and monitoring, control, research and development, education, training information, and communication related to environmental protection or resource management (S4)

2. Environmental sole-purpose products: goods or services whose use directly serves an environmental protection or resource management purpose and that have no use except for environmental protection or resource management. Examples include catalytic converters, septic tanks, and the installation of renewable energy production technologies. (S5)

3. Adapted goods: goods that have been specifically modified to be more "environmentally friendly" or "cleaner" and whose use is therefore beneficial for environmental protection or resource management. Adapted goods differ from environmental specific services and solepurpose products, as they do not have a primary purpose of environmental protection or resource management

a) Cleaner goods that help to prevent pollution or environmental degradation because they are less polluting at the time of their consumption and/or scrapping compared to equivalent "normal" goods. Equivalent normal goods are goods that provide similar utility except for the impact on the environment Examples are mercury free batteries and cars or buses with lower air emissions. (S6)

b) Resource efficient goods that help to prevent natural resource depletion because they contain less natural resources in the production stage (for example, recycled paper and renewable energy, heat from heat pumps and solar panels) and/or in the

${ }^{1}$ For later discussion of the statistics, we number the proposals consecutively. 
use stage (for example, resource efficient appliances, watersaving devices such as tap filters, desalinated water). (S7)

4. Environmental technologies: technical processes, installations and equipment, and methods or knowledge whose technical nature or purpose is environmental protection or resource management

a) End-of-pipe (pollution treatment) technologies which are mainly technical installations and equipment produced for measurement, control, treatment and restoration/correction of pollution, environmental degradation, and/or resource depletion. These installations and equipment operate independently of, or are identifiable parts added to, production and end-life consumption cycles. Examples include equipment to measure soil erosion, and facilities for the containment of high-level radioactive waste. (S8)

b) Integrated technologies (pollution prevention) are technical processes, methods or knowledge used in production processes that are less polluting and resource intensive than the equivalent "normal" technology used by other national producers. Their use is less environmentally harmful than relevant alternatives. (S9)

\subsection{US Bureau of Labour Statistics}

\section{Main source: http://www.bls.gov/green/\# overview}

The US Bureau of Labor Statistics (BLS) has developed a framework for the collection of data on "green jobs". The purpose of the initiative is to produce information on the trends and number of green jobs, the industrial, occupational, and geographic distribution of the jobs, as well as the wages of employees in these jobs.

\subsubsection{Intention}

The intention is to use the information for evaluating policy initiatives and the labour market impact of economic activity related to protecting the environment and conserving natural resources. 


\subsubsection{Specification of statistics}

The BLS defines green jobs in two main categories:

- Jobs in businesses that produce goods and provide services that benefit the environment or conserve natural resources. These goods and services are sold to customers, and include research and development, installation, and maintenance services. Green goods and services fall into one or more of the following groups:

a) Energy from renewable sources. Electricity, heat, or fuel generated from renewable sources. These energy sources include wind, biomass, geothermal, solar, ocean, hydropower, and landfill gas and municipal solid waste. (S10)

b) Energy efficiency. Products and services that improve energy efficiency. Included in this group are energy-efficient equipment, appliances, buildings, and vehicles, as well as products and services that improve the energy efficiency of buildings and the efficiency of energy storage and distribution, such as Smart Grid technologies. (S11)

c) Pollution reduction and removal, greenhouse gas reduction, and recycling and reuse. These are products and services that reduce or eliminate the creation or release of pollutants or toxic compounds, or remove pollutants or hazardous waste from the environment, reduce greenhouse gas emissions through methods other than renewable energy generation and energy efficiency, such as electricity generated from nuclear sources or reduce or eliminate the creation of waste materials; collect, reuse, remanufacture, recycle, or compost waste materials or wastewater. (S12)

d) Natural resources conservation. Products and services that conserve natural resources. Included in this group are products and services related to organic agriculture and sustainable forestry; land management; soil, water, or wildlife conservation; and storm-water management. (S13)

e) Environmental compliance, education and training, and public awareness. These are products and services that enforce environmental regulations, provide education and training related to green technologies and practices or increase public awareness of environmental issues. (S14)

- Jobs in which workers' duties involve making their establishment's production processes more environmentally friendly or use fewer natural resources. These workers research, develop, or use technologies and practices to lessen the environmental impact of 
their establishment, or train the establishment's workers or contractors in these technologies and practices. This definition will be used in the BLS survey of establishments across all industries to identify jobs related to green technologies and practices used within the establishment. These technologies and practices fall into one or more of the following groups:

a) Energy from renewable sources. Generating electricity, heat, or fuel from renewable sources primarily for use within the establishment. These energy sources include wind, biomass, geothermal, solar, ocean, hydropower, and landfill gas and municipal solid waste. (S15)

b) Energy efficiency. Using technologies and practices to improve energy efficiency within the establishment. Included in this group is cogeneration (combined heat and power). (S16)

c) Pollution reduction and removal, greenhouse gas reduction, and recycling and reuse. Using technologies and practices within the establishment to Reduce or eliminate the creation or release of pollutants or toxic compounds, or remove pollutants or hazardous waste from the environment, reduce greenhouse gas emissions through methods other than renewable energy generation and energy efficiency, or reduce or eliminate the creation of waste materials; collect, reuse, remanufacture, recycle, or compost waste materials or wastewater. (S17)

d) Natural resources conservation. Using technologies and practices within the establishment to conserve natural resources. Included in this group are technologies and practices related to organic agriculture and sustainable forestry; land management; soil, water, or wildlife conservation; and storm-water management. (S18)

\subsection{The Green Jobs Initiative - UNEP, ILO, ITUC}

\section{Main source: UNEP (2008a, b)}

The Green Jobs Initiative is a joint initiative by the United Nations Environment Programme (UNEP), the International Labor Organization (ILO) and the International Trade Union Confederation.

The initiative "supports a concerted effort by governments, employers and trade unions to promote environmentally sustainable jobs and development in as climate-challenged world" (UNEP 2008a, p.4). Particular emphasis is put on "decent" jobs - pairing concerns like efficiency 
and low emissions with traditional labour concerns including wages, career prospects, job security, occupational health and safety as well as other working conditions, and worker rights.

\subsubsection{Intention}

Intentions are such as to identify knowledge gaps, promote policies and measures to achieve green jobs, catalyse employment and poverty alleviation within climate mitigation and adaptation.

\subsubsection{Specification of statistics}

The definition of green jobs are such as positions in agriculture, manufacturing, construction, installation, and maintenance, as well as scientific and technical, administrative, and service-related activities, that contribute substantially to preserving or restoring environmental quality. Specifically, but not exclusively, this includes jobs that help to protect and restore ecosystems and biodiversity; reduce energy, materials, and water consumption through high-efficiency and avoidance strategies; decarbonize the economy; and minimize or altogether avoid generation of all forms of waste and pollution. UNEP argue that green jobs also need to be good jobs that meet longstanding demands and goals of the labour movement, i.e., adequate wages, safe working conditions, and worker rights, including the right to organize labour unions (UNEP 2008b, p. 35).

\subsection{Metropolitan Policy Program}

\section{Main source: Muro et al. (2011)}

The Metropolitan Policy Program estimates the extent of the US "clean economy". The purpose of the statistics is to make the information about the clean economy as widely available as possible while providing the greatest possible flexibility to users.

\subsubsection{Specification of statistics}

The program defines the clean economy as economic activity, measured in terms of establishments and the jobs associated with them, that produces goods and services with an environmental benefit or adds value to such products using skills or technologies that are uniquely applied to those products. 
Key aspects of the definition, categorization, and approach draw from previous definitional and measurement work by Eurostat and the OECD as well as by the U.S. Environmental Protection Agency (EPA) and the U.S. Bureau of Labor Statistics (BLS). It is meant to be an economic development study focused tightly on clean economy business establishments and the jobs they create. The framework is primarily the establishments and jobs of U.S. enterprises whose products have an environmental benefit, either inherently, like environmental remediation services or relatively, like organic food or solar panels.

The statistics define five categories for the clean economy, with further specified industry segments:

- -Agricultural and natural resources conservation

- Education and compliance

- Energy and resource efficiency

- Greenhouse gas reduction, environmental management and recycling

- Renewable energy 


\section{Evaluation of the statistical frameworks}

In this chapter, we aim to analyse whether the proposed statistics in the UN/Eurostat/BLS initiatives provide relevant answers to the intentions behind the statistical initiatives. First, we start out with an attempt to summarize the intentions as expressed in the frameworks discussed above (3.1). Then we summarize main characteristics of the statistics (3.2). Finally, (in 3.3) we discuss whether the statistics (3.2) are suitable to give answers to the stated need for data (3.1).

\subsection{The intentions of the statistics}

The main intentions listed are in short:

- to permit cross-country comparison and assessment of best practice (the EGSS, section 2.1 above)

- to provide information on the extent to which the economy may become more environmentally friendly and resource efficient (the EGSS, section 2.1)

- to assess the extent to which the economy is responding to various public policies and initiatives that have this objective in mind (the EGSS, section 2.1)

- to evaluate policy initiatives and the labour market impact of economic activity related to protecting the environment and conserving natural resources (the BLS, section 2.2)

- to identify knowledge gaps, promote policies and measures to achieve green jobs, catalyse employment and poverty alleviation within climate mitigation and adaptation (the Green Jobs Initiative, section 2.3)

Both the UN/Eurostat EGSS framework and the BLS are concerned with the effects of policy instruments and the economic development, included within the labour market, on the environmental development.

Basically, the goals of the statistics seem to concentrate on three main categories, see also Table 1: 
A. First, a motive is to quantify the activities' effects on the environmental state and the potential for environmentally friendly and resource efficient activity in the economy, confer 1) and 2) above. To evaluate whether the economy becomes more environmentally friendly, insight into the environmental state and changes in the environmental state is inherently necessary.

B. Second, a focus is on the environmental responses to environmental policy and economic development, confer points 2) - 3) above.

C. Third, the economic responses, including employment and value added, to environmental policy confer points 2) - 5) above.

Table 1 Motivations underlying the international initiatives in three main categories

\begin{tabular}{|c|c|c|c|}
\hline & $\begin{array}{l}\text { A. } \\
\text { Effects on the environ- } \\
\text { mental state and the } \\
\text { potential for environmen- } \\
\text { tally friendly and resource } \\
\text { efficient activity }\end{array}$ & $\begin{array}{l}\text { B. } \\
\text { The environmental } \\
\text { responses to environ- } \\
\text { mental policy and } \\
\text { economic development }\end{array}$ & $\begin{array}{l}\text { C. } \\
\text { The economic re- } \\
\text { sponses, including } \\
\text { employment and } \\
\text { value added, to } \\
\text { environmental policy }\end{array}$ \\
\hline $\begin{array}{l}\text { 1) cross-country comparison } \\
\text { and assessment of best } \\
\text { practice }\end{array}$ & $x$ & & \\
\hline $\begin{array}{l}\text { 2) the extent to which the } \\
\text { economy may become more } \\
\text { environmentally friendly and } \\
\text { resource efficient }\end{array}$ & $x$ & $x$ & $x$ \\
\hline $\begin{array}{l}\text { 3) to which the economy is } \\
\text { responding to various public } \\
\text { policies and initiatives }\end{array}$ & & $x$ & $x$ \\
\hline $\begin{array}{l}\text { 4) evaluate policy initiatives } \\
\text { and the labour market impact } \\
\text { of economic environmentally } \\
\text { friendly activity }\end{array}$ & & & $x$ \\
\hline $\begin{array}{l}\text { 5) identify knowledge gaps, } \\
\text { policies to achieve green } \\
\text { jobs, employment and } \\
\text { poverty alleviation }\end{array}$ & & & $x$ \\
\hline
\end{tabular}

\subsection{The statistics}

After a review of the EGSS and the BLS initiatives, the statistics may be categorized into three main groups, see Table 2 . The specified statistics are numbered in Chapter 2 (S1-S18). 


\begin{tabular}{lll}
\hline & Table 2 Summary of activities aggregated in main categories & \\
\hline & Activities & $\begin{array}{l}\text { Identified activities in } \\
\text { Chapter } 2\end{array}$ \\
\hline Prevention & $\begin{array}{l}\text { activities preventing or minimizing pollution before coming } \\
\text { into being, including environmental protection, natural } \\
\text { resources conservation, resource management and education } \\
\text { etc increasing knowledge and environmental awareness }\end{array}$ & $\begin{array}{l}\text { S1, S4, S5, S13, S14 } \\
\text { and S18 }\end{array}$ \\
Relative damages & $\begin{array}{l}\text { goods or technologies that are considered to have relatively } \\
\text { low pollution or resource intensity }\end{array}$ & $\begin{array}{l}\text { S6, S7, S9, S10, S11, } \\
\text { S15 and S16 }\end{array}$ \\
Mitigation & $\begin{array}{l}\text { treatment of the environmental damages that have taken } \\
\text { place, treatment and management of pollution and repairing } \\
\text { of damages }\end{array}$ & $\mathrm{S} 2, \mathrm{~S} 3, \mathrm{~S} 17, \mathrm{~S} 12$ and \\
\hline
\end{tabular}

The first category "Prevention" comprises activities preventing or minimizing pollution before coming into being. The second category, "Relative damages", includes goods or technologies that are considered to have relatively low pollution or resource intensity, while "Mitigation" comprises treatment of the environmental damages that have taken place, treatment and management of pollution and repairing of damages.

\subsection{Do the statistics match the intentions?}

The question now is what information best serves as answers to the intentions, as summarized in 3.1, and whether the statistics in 3.2 are best suited to offer such information.

As discussed in A.-C. above, we find that the intentions focus on three dimensions: the level and potentials of environmental pressure; environmental responses; and the economic and employment responses.

\subsubsection{The level and potential of environmental pressure}

None of the three groups of statistics (prevention, relative damages, mitigation) provide information on environmental pressure. The prevention and mitigation statistics comprise activities before and after pollution occurs. The relative damages comprise statistics on technologies with relatively low pollution intensity, but the statistics do not measure the level or the potential pressure. To measure the environmental pressure, also the remaining sectors in the economy need to be included. Emissions and other environmental pressure from each activity need to be measured, not only those labelled as part of the green sector.

Likewise, the suggested statistics do not provide information to analyse the potentials for the environmental changes, and jobs associated 
with different activities. Such analyses also require data on all sectors, with specifications of the sectors' environmental impact. Importantly, the main potential for emission reductions are found in the most polluting sectors, which are typically excluded from the EGSS etc. frameworks. Principally the potential is 100 per cent of the economy, given that the necessary costs are accepted.

\subsubsection{Responses to environmental policy}

The environmental response perspective relates to how environmental policies influence the economic activities and the economy's impact on the environment. The statistics do not offer appropriate information to cast light on these issues. Generally, increasing activities in environmental protection and resource management reflects better economic conditions for such activities, but they do not indicate any effects on changes in environmental damages.

To investigate the policy responses, analytical tools like econometric studies linking instruments, economic activities and emissions, or macroeconomic models typically provide the most accurate estimates. All agents facing economic restrictions in terms of e.g. pollution taxes or waste charges will respond to some degree by preventing emissions and waste generation. Normally, the more the emission costs increase, the stronger are the responses. Higher pollution costs will be transmitted through the market prices to principally all parts of the economy, e.g. through higher prices on products based on fossil fuel intensive technologies.

Therefore, we cannot point out some sectors ex ante as more important to the environmental responses than others. Also, the size of the responses is not absolute, but varies from case to case. For example, the household sector will also respond to environmental policies, but households are not included in the green statistics.

In addition to policy instruments, general technological progress is one of the main causes for reduced environmental pressure over time. E.g. in Norway on average energy per produced unit has been reduced by 1,4 per cent yearly over the two last decades (in total 24 per cent). The partial effect of technological progress is a general reduction of the environmental pressure, with varying effects between sectors. For instance, some industries have improved energy efficiency more than some service sectors. In other words, it is not possible or meaningful to single out any particular sector as being more technologically responsive to environmental regulations or general economic development than others. 


\subsubsection{The economic and employment responses}

The third category of motives for the statistics is the economic responses and the effects on employment from greening of the economy. The green job concept combines two principally independent goals; high employment and sustainable development. Both a clean environment and low unemployment are positive aspects of a well-functioning future economy. But there is no obvious causal link between these two goals. For instance, increasing employment in waste handling activities may imply higher priority to emissions from waste treatment and the potential gains from recycling. But it may also express that employment is less efficient or that the waste industry is subsidized due to other concerns. It is neither possible to identify whether pollution from waste is high, requiring a higher employment rate, or low, due to low emissions per employed worker.

The EGSS etc. initiatives do not provide information on how environmental policies affect economic variables, such as employment. As argued in the section above, detailed analytical tools like econometric studies or macroeconomic models typically provide the most accurate estimates of policy effects.

\subsection{Examples of quantification}

The OECD (2011) uses the UN / Eurostat EGSS approach. In order to compare statistics across countries, the data must be normalized. OECD proposes to assess the progress towards green growth by the share of the EGSS in terms of e.g. employment and value added, see Figure 1and Figure 2. The sectors presented in Figure 1 include recycling, collection, purification and distribution of water, sewage and refuse disposal, sanitation and similar activities, and the share of "green" enterprises in Figure 2 , include retreating, recycling, collection, purification and distribution of water. 
Figure 1 Employment in the environmental goods and services sector, 2002, 2007, selected EU countries, as per cent of total employment

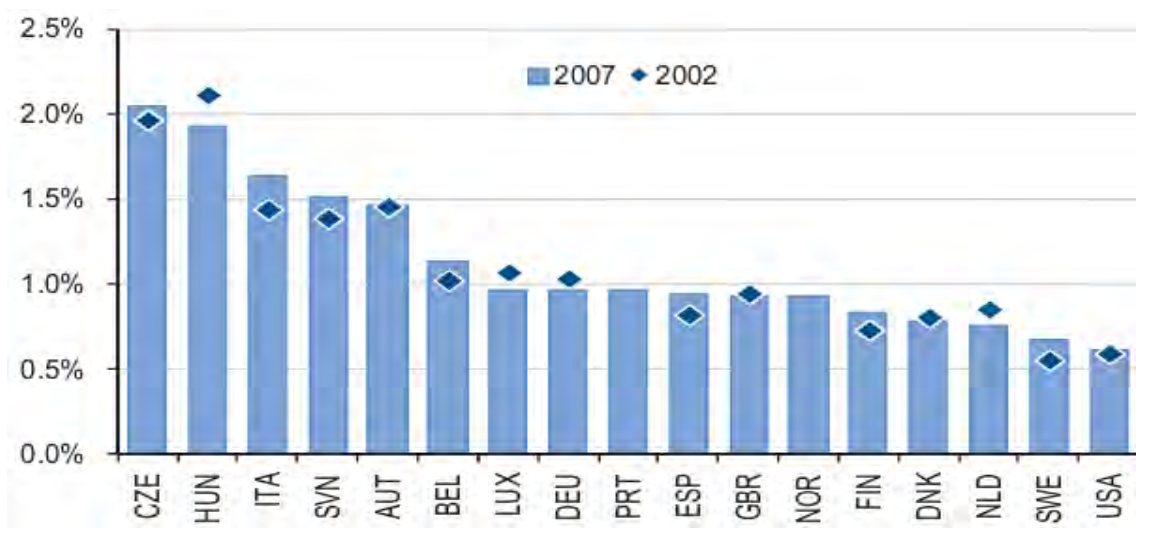

Source: OECD (2011)

Figure 2 Enterprises in the environmental goods and services sector, 2002, 2007, selected EU countries, as per cent of the number of enterprises

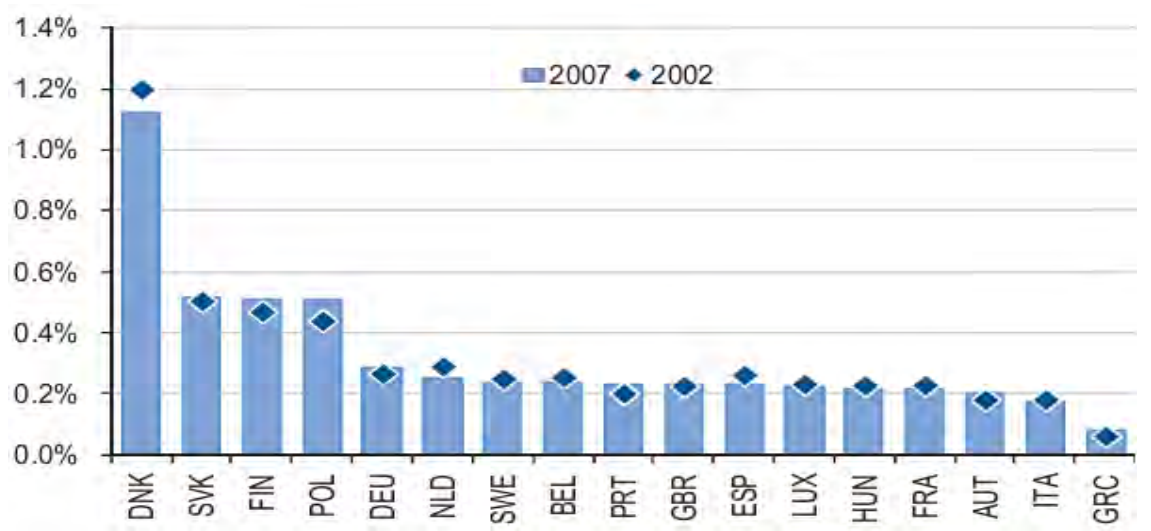

Source: OECD (2011)

It is unclear how the statistics can be interpreted in an environmental context. The figures do not provide information on whether a higher share of employment is good or bad for the environment, as the indicators are ambiguous as to whether they represent the influence of environmental policy or environmental state. For instance, it is not clear from the indicators whether the higher share of employment in the EGSS sector in the Czech Republic, Hungary and Italy is an indicator of a higher environmental awareness and priority than in the Nordic countries (Figure 1). Another example is the higher share of EGSS enterprises and 
employees in Denmark compared to Sweden. It is not clear whether this implies less efficient waste, sewage and refuse handling system in Denmark, whether more people employed in EGSS is due to larger environmental problems, or whether Denmark prioritizes recycling, collection, purification and distribution of water, sewage and refuse disposal, sanitation and similar activities significantly more than other countries.

Because the indicators are expressed as shares of total employees and number of enterprises, the general level of employment and economic activity is also central factors explaining the variation in EGSS employment rates (Figure 1) or EGSS enterprise shares (Figure 2)

OECD (2011) is rather critical to the use of the data, as defining the boundaries for the set of environmental goods and services remains difficult as do their measurement and interpretation. OECD concludes that most indicators used to describe entrepreneurial performance are not available at the level of detail required to capture activities characterised as "green".

Other examples of the definitions of sectors and associated establishments and jobs are illustrated in Table 3-Table 5. The US BLS estimates that green goods and services are present in more than 2 mill. establishments in the US (Table 3), the Jobs Initiative estimates that 2,2 mill people are employed in the renewable energy sector around the world (Table 4), and the Metropolitan Policy Program estimates that the clean economy employs some 2,7 million workers in the US economy (Table 5). However, it is not stated what this information can be used for, e.g. as basis for efficient policy formulation to meet the most pressing environmental challenges (II), or as basis for analyses of the environmental state and potential in different sectors (I).

Table 3 Number and per cent distribution of establishments in industries where green goods and services are classified, by industry sector, 2009

\begin{tabular}{lrr}
\hline Industry sector & $\begin{array}{r}\text { Number of } \\
\text { establishments }\end{array}$ & $\begin{array}{r}\text { Percent } \\
\text { distribution }\end{array}$ \\
\hline Construction & 820,700 & 38.1 \\
Professional and business services & 779,100 & 36.2 \\
Other services (repair and maintenance services, professional organizations) & 183,300 & 8.5 \\
Natural resources and mining & 88,700 & 4.1 \\
Information & 77,000 & 3.6 \\
Manufacturing & 77,700 & 3.6 \\
Trade, transportation, and utilities & 49,300 & 2.3 \\
Public administration & 42,100 & 2.0 \\
Education and health services & 26,400 & 1.2 \\
All other sectors & 10,400 & 0.5 \\
Total & $2,154,700$ & 100 \\
\hline
\end{tabular}

Source: http://www.bls.gov/green/\#overview 
Table 4 Employment estimates in the renewable energy sector, global and selected countries, 2006

\begin{tabular}{llr}
\hline Renewable energy source & World / selected countries & Employment, 1000 \\
\hline Wind & World & 300 \\
Solar PV & World & 115 \\
Solar thermal & China, Europe, USA & $624+$ \\
Biomass/biofuels & Brazil, USA, China, Germany & 1,174 \\
Hydropower & Europe, USA & 39 \\
Geothermal & USA, Germany & 25 \\
Renewables, combined & & 2,277 \\
\hline
\end{tabular}

Source: UNEP (2008a)

Table 5 Segments of the clean economy in the US economy, 1000 jobs, 2010

$$
\text { Sector }
$$

Number of jobs

$\begin{array}{lr}\text { Agricultural and natural resources conservation } & 506 \\ \text { Education and compliance } & 142 \\ \text { Energy and resource efficiency } & 830 \\ \text { Greenhouse gas reduction, environmental management and recycling } & 1,059 \\ \text { Renewable energy } & 138\end{array}$

Source: Muro et al. (2011) 


\section{Discussion of the framework}

The EGSS, BLS and other initiatives made to measure green activities divide the economy into one green sector, and, implicitly, a non-green sector. There are several problems with this delimitation, as we will outline below.

\subsection{Principal objections}

\section{All activities are more or less green}

All activities bring along some level of environmental pressure, i.e. all activities are principally more or less green/non-green. The correct description of green versus non-green is thus along a continuous scale, while the above mentioned initiatives rely on subjectively set borders dividing the scale into two parts.

For example, renewable energy is typically labelled as green, while fossil fuels are considered non-green. Hydro and wind power plants and biofuels may involve dams, degradation of pristine areas, carbon emissions from deforestation, methane emissions, reduced biodiversity and use of energy input. The petroleum sector creates carbon emissions and other environmental problems, and is typically not included as a green sector. But gas production is relatively clean compared to other energy sources, such as coal and in some instances also compared to biofuels. If gas substitutes carbon intensive energy carriers, emissions can be significantly reduced, while other environmental degradation may increase if renewable energy production increases. In other words, both types of energy production involve emissions to some degree.

Since "greenness" is a relative term, it is not possible to define consistent and mutually exclusive activities as being more environmentally relevant than others.

The categorization implies unsystematic valuation of externalities Environmental costs are external costs, and hence not valued in the market. Since the values of e.g. global warming and local pollution cannot be read from the market prices, the valuation is principally normative. Values will differ between individuals according to their personal 
preferences. Calculations on environmental costs must hence rely on estimates, preferably accounting for the society's preferences as expressed by the individuals. Environmental economics theory offers several methods for estimating the values of environmental externalities, the most important being contingent valuation, hedonic pricing, travel costs, choice experiments and market-based methods (see, e.g., Pearce and Turner 1990). The estimates differ with method, and can only be taken as indicators of the environmental costs, not as objective statistics. When aggregating different environmental damages, the total cost estimates become even more uncertain.

The result of a damage cost analysis will rely on the scientist's subjective choices. It is thus particularly important to supply the analysis with transparent information on methods and what cost estimates are used.

By defining some activities as green and others as non-green, the producer of the statistician has implicitly made subjective evaluations of the total environmental costs. For example, the implication of regarding renewable energy as green and non-renewable as non-green, is that the valued costs of lost recreational values, methane emissions costs, reduced biodiversity and other costs related to hydro-power dams are lower than the carbon emission and other costs related to gas power production.

Implicitly, such evaluations underlie all categorization of green sectors, technologies and jobs, as in the EGSS framework. The categorization hence implies valuation of environmental externalities, without explicitly explaining the valuation criteria, and without being based on scientific and transparent foundation as described above.

\section{The environmental outcome relies on market interactions}

The direct environmental effects from an activity are not sufficient to predict the total, net effects. For example, recycled paper may reduce use of energy and other resources associated with the production process from forestry to the paper mill. The total effect however, relies on the interplay with other parts of the market. Increased supply of paper into the market reduces prices and may increase total paper consumption and the consumption mix, principally leaving the total environmental effects an empirical question. Increased wind power contributes to lower energy prices and less profitability in fossil fuel production. Also, this implies lower incentives for technology innovation and energy savings. In a system with emission trading, as in the EU ETS, emissions in other sectors will increase, leaving net carbon emissions unchanged. 
In other words, it is principally not possible to mark specific activities with green labels, as the net effects are time and case specific and dependent on economic general equilibrium effects.

\subsection{Specific comments to the EGSS framework}

Due to the lack of principal definitions, the specifications of the EGSS, BLS etc. statistics described in Chapter 2 unfold several problems. We will discuss some examples related to the EGSS framework below:

- The purpose perspective: The EGSS delineates environmental activities from others by only including those that relate to environmental activities, i.e. "those economic activities whose primary purpose is to reduce or eliminate pressures on the environment or to make more efficient use of natural resources" (UN 2011; 1.110). In principle, no activity has environment as its main purpose. All activities are driven by the incentives of maximizing output/profit at given costs, no matter what is produced (education, steel, renewable energy or waste treatment). For example, the sole-purpose products include goods or services whose use directly serves an environmental protection or resource management purpose and that have no use except for environmental protection or resource management (UN 2011; 4.99). From this perspective, products and service like septic tanks, city sewage systems and municipal litter collection are labelled green. In an economic perspective, these activities are necessary counterparts to human consumption and settlement. The principal difference between these activities and many other municipal services, such as road maintenance, is not obvious. Waste water and firms in the waste and recycling sector seek to maximize profit like other firms, and constitute a significant part of the economy. Reducing the environmental pressure is one effect of the external prices and regulations in the market

- Adapted goods: These include goods that have been specifically modified to be more "environmentally friendly" or "cleaner". It is not possible to draw principal lines between goods that have and have not become more environmentally friendly. All products change over time. Due to general technological progress, most production becomes less resource intensive and hence more environmentally friendly. For example, the benefits from using more efficient inputs, such as electronic deliveries substituting physical delivery are excluded from the EGSS. Such technologies involve a more efficient 
use of natural resources in the same way as the elements included in the EGSS, such as recycling paper. The incentives for production and use of recycled materials are purely economical as long as it is cheaper than raw material

- Lack of principals creates needs for exceptions: The EGSS framework excludes "goods and services produced for purposes that, while beneficial to the environment, primarily satisfy technical, human, and economic needs or that are requirements for health and safety" and "goods and services related to minimizing the impact of natural hazards and those related to the extraction, mobilisation and exploitation of natural resources" (UN 2011; 4.105). Obviously, all goods and services satisfy other needs than the environmental to some degree. These exceptions bring up another need for subjective categorization of continuous factors (technical, human an economic needs, health and safety) into discontinuous groups. The lack of consistent definitions complicates the interpretation of the excepted activities, as well as those included

- Households are not included: The households contribute to a large share of pollution. They are main actors when it comes to commonly considered core environmentally friendly activities, such as household collection and sorting of waste, insulation of buildings. Following the EGSS definition, these activities should be included in the green sector, along with such activities in the waste treatment sector. Also, all buildings, regardless of their other activities, have internal wastewater treatment systems which principally should fall under the concept of the EGSS. Despite its size, the household sector is not included

- How to interpret the pollution treatment activities? End-of-pipe technologies and the extent of activities related to managing pollution and repairing damages to nature do not provide information to the main questions motivating the statistics. They do not indicate the extent of the present or future environmental problems or policy responses, neither do they indicate whether present abatement is efficient. Rather, future environmental costs and need for repair rely on planned policy, the development of our knowledge on the inter-linkages in ecosystems and how to impact them, in addition to general technological development and market conditions 
- No information on responses to environmental policy: According to the EGSS, the statistics should "assess the extent to which the economy is responding to various public policies and initiatives". Any environmental policy, such as environmental taxes, will principally influence all parts of the economy via changes in relative prices. The price effects will be spread via goods and services throughout the market. Sorting out specific activities that contribute to environmental improvements will not give the correct answer, due to the entanglement of general equilibrium effects and mutual dependency between activities. For example, $\mathrm{CO}_{2}$ taxes will prevent and reduce air emissions both in resource management services, waste treatment, energy intensive industries as well as households, but the two latter sectors are not included in the definition of green sectors. The more the policy corrects the environmental costs, the more optimal is the allocation of resources and the production mix, regardless of the distribution of damages over activities. In other words, it is not possible to assess the responses of policies by only studying a selected part of the economy

- Largest environmental potentials excluded: The EGSS emphasises "the potential for economic activity and employment to be based on environmentally friendly and more resource efficient activities" (UN 2011 ; 4.94). Principally the potential is 100 per cent of the economy, given that the necessary cost is accepted. The most polluting industries, which are excluded from the green sectors, may represent the highest potentials, while the possibilities to reduce emissions in relatively clean technologies are low. Hence the green sectors typically exclude those with the largest potentials

\subsection{Critical views in other reports}

Several other studies have expressed the same scepticism to this approach.

The World Bank (2012) points to the fact that the concept of green jobs still lacks a clear definition and greater scrutiny is warranted to evaluate the extent of green job creation. They also express scepticism towards green policy as a means to address structural unemployment, and instead point to the importance for removing market distortions and stimulate educations where skills are lacking. Rather than using green growth as a means to solve unemployment.

In a general note, OECD (2011) points to the fact that the scope for monitoring progress remains limited, and questions whether the poten- 
tial for green growth is adequately captured. OECD points to several weaknesses related to the EGSS framework:

- They argue that production of environmental goods, services and technologies is only one aspect of the potential for green growth, as an economy could move towards a low carbon growth path if traditional industries increase their energy efficiency through new modes of organisation or product innovation that leads to products that are less energy intensive in their use, triggered by cost or competitiveness considerations rather than environmental concerns

- Most indicators used to describe entrepreneurial performance are not available at the level of detail required to capture activities characterised as "green"

- EGSS includes products that are produced with an environmental purpose as the main purpose. This implies arbitrariness in the categorization, as e.g. eco-efficient devices are included, while electronic deliveries of documents are not although this substitutes physical deliveries and provides savings in paper and energy for transport

- For producing units some activities may fall under the definition of EGSS, such as in-house waste collection, while since these are ancillary activities, they are not captured by the statistics

- When some environmental technologies, goods or services are used in the production of another environmental product, including both activities would imply double-counting.

- An economy can turn green without necessarily being engaged in the production of green goods and services because processes of production become more environmentally efficient

- OECD concludes that despite existing definitions, setting the boundaries of the set of environmental goods and services remains difficult as do their measurement and interpretation

In a discussion of the international attempts to measure green sectors, Pöyry (2011) concludes that it is difficult to make precise delimitations of green sectors, even for sectors with a clear main focus on producing environmentally friendly solutions. They point to the same problems as mentioned above: 
- Many businesses produce mixed products with more or less environmentally friendly profiles

- Even the most typical green sectors can have negative environmental impacts

- Fossil fuel producers can be less polluting than the alternatives

- Energy intensive products can substitute more energy intensive products (e.g. aluminium vs. steel)

- Increasing share of low polluting sectors positively affect the environment without being labelled as green (e.g. the services sector)

- What is typically defined as green sectors will change over time as new technologies are developed within and across existing sectors

\subsection{An alternative approach}

As summarised in chapter 3.1, the main purpose of the initiatives are:

- to quantify the environmental state and the potential for environmentally friendly and resource efficient activity in the economy

- to identify the environmental responses to environmental policy and economic development

- to study the economic responses, including employment and value added, to environmental policy

The most nearby information bases for the environmental state and potentials reductions (I) are the national emission inventories, providing emission statistics per sector/activity. The environmental load is ascribed to the direct effects of the production and consumption processes and to the activity where the emissions occur. For comparisons, emissions per sector can be measured in terms of monetary units (per produced unit) or per employed worker. This framework requires detailed data on:

- Environmental impact (for instance emissions to air, water, land, noise, biodiversity etc)

- Production

- Employment

This information does not require subjective selections of green and non-green sectors, but offers objective information from which the users 
can draw own evaluations on where the problems are more or less pressing, and where action is needed. Instead of absolute greenness, subdividing the economy into two categories as proposed by e.g. the EGSS, the existing statistics provides information on relative greenness, possibly ranging the activities along a continuous scale

To assess the responses to various public policies and initiatives (II and III), econometric analyses of the relationship between instruments and economic and environmental factors reveal possible causal relationships as basis for policy formulation. Such studies require detailed information on the instruments, such as tax rates and regulations per sector/activity.

This main proposal is further elaborated in Chapter 8. 


\section{Green statistics in the Nordic countries}

This chapter contains a review of the relevant statistical initiatives, concepts and quantifications in the Nordic countries.

\subsection{Denmark}

Two studies, initiated by the Danish EPA, have undertaken a comprehensive mapping and quantification of the EGSS sector in Denmark and its strongholds (FORA 2006, FORA 2009). In addition to the FOR A studies, two other mapping exercises have been undertaken in 2008 (Økonomi- og Erhvervsministeriet 2008, Vækstfonden 2008). Both of these mapping exercises along with the FORA 2006 study provided a basis for the 2009 FORA study. We therefore refer only to the FORA (2009) study in the following.

\subsubsection{Definitions}

The definition of organisations within the EGSS sector applied in the FORA studies is based on three criteria, of which the organisations must qualify for at least one:

1. Enterprises developing and selling solutions, products or technologies that directly improve the environment when applied (e.g. renewable energy or water treatment technologies) (Environmental sole-purpose products \& Environmental technologies)

2. Enterprises developing and selling solutions, products or technologies that pose less pressure on the environment through an improved use of resources (e.g. low-energy windows and new recycling technologies) (Adapted goods)

3. Enterprises developing and selling solutions or consulting that pose less pressure on the environment through optimization and increased efficiency of processes (Environmental specific services) 
The criteria applied in order to identify environmental technology organisations fall within the scope of EGSS as defined by Eurostat and the UN (See Section 2.1). The four types of EGSS defined by Eurostat are listed in square brackets above.

The identification of organisations that comply with at least one of these criteria implies a broad delimitation of the EGSS sector. Especially for criteria \#2 and \#3, organisations whose business model and ethics are based on reducing pressure on the environment would be included in the EGSS sector, even if the company operates in a sector not traditionally perceived as being of the environmental area.

In addition, the Danish EPA operates with the following definition of Eco-efficient technology: "Eco-efficient technology means all technologies which directly or indirectly improve the environment. It includes technologies to limit pollution through decontamination, more environmentally friendly products and production processes, more effective resource management, and technological systems to reduce environmental impacts. Reduced environmental impacts must not necessarily be the primary objective of an eco-efficient technology. This interpretation is in accordance with the EU and OECD definition of "environmental technology" (Danish Government \& www.ecoinnovation.dk)

Eight environmental areas were identified in terms of number of enterprises and employees. In order to identify companies operating within each of these eight areas, characteristics of the solutions were set up (FORA 2009):

- Climate change: solutions, technologies or products that lead to a reduced emission of greenhouse gasses, i.e. through a reduced energy consumption in relation to consumption or production. Renewable energy is included here.

- Water: solutions, technologies or products that have already or will lead to a reduced consumption of water, e.g. in connection with irrigation, industrial production, households and heating, lead to reduced pollution of surface water and groundwater or which treats waste water.

- Air pollution: solutions, technologies or products that lead to a reduced air pollution. This includes both end-of-pipe technologies and products that lead to a reduced emission of harmful substances to the air.

- Chemicals in products: solutions, technologies or products where the content of one or more environmental or health related problematic substances is reduced or avoided (e.g. heavy metals, phthalates, 
brominated flame retardants) in material, consumer goods, pest control etc.).

- Waste: solutions, technologies or products that lead to reduced amounts of waste or less hazardous waste including waste management technologies, treatment technologies, cleaner technologies that produce less waste and use of waste products;

- Soil pollution: solutions, technologies or products that lead to reduced soil pollution. This includes both soil remediation technologies and technologies or products that lead to less soil pollution including different sorts of leakages.

- Resource and use of materials: solutions, technologies or products that lead to a reduced use of resources and raw materials, including both renewable resources such as wood and non-renewable resources such as metals and oil.

- Land use and biodiversity: solutions, technologies or products that lead to a reduced need for land use and technologies or production methods that contribute to the conservation of biodiversity, e.g. in relation to agriculture, forestry and fisheries.

Through the use of the snow-ball technique ${ }^{2}$ and desk research, a total of 720 companies employing some 120,000 full-time equivalent staff were defined as related to the EGSS sector in the 2009 study. This represents about 4.4 per cent of total number of employees in Denmark. Turnover of the sector represented more than 300 billion DKR (2006 numbers). Of this 40 per cent was exported. Table 6 shows the key figures of the Danish EGSS sector.

Table 6 Key figures for the Danish EGSS sector

\begin{tabular}{lr}
\hline FTE employees (1000s) & $\mathbf{1 2 2}$ \\
\hline Number of companies & 720 \\
Turnover (bio. DKR) & 328 \\
Export (bio. DKR) & 130 \\
Export share (pct.) & 40 \\
Value added (bio DKR) & 86 \\
Value added per employee (1000s DKR) & 705 \\
\hline
\end{tabular}

Source: FORA (2009)

2 The snow-ball method is a recognised sociological method to identify and map specific groups that are not easily attainable from existing data. It works by sending requests for information to relevant enterprises within the EGSS sector in order to obtain references of other enterprises within the search criteria. The new enterprises are then asked for references to yet other companies and the 'snow ball continues until the population is deemed fully identified. 
FORA undertook a methodologically identical survey during 2005 and updated the survey in 2009. The number of companies identified within the sector between 2005 and 2009 increased from 420 to 720. FORA estimates that ca. 20 per cent of the new identified companies were established after 2005 and between 30 to 40 per cent changed strategy towards environmental protection or improved resource use. The remainder were not identified during the 2005 mapping exercise.

Number of companies and employees by the eight environmental areas are illustrated in Figure 3 below. The data collection method used did not make it possible to identify the share of employees within each organization that work directly with environmental technologies, hence number of employees should be considered with care.

Companies working within the area of climate change represent the largest group within the environmental technology sector, representing some 45.000 employees in 2005 (ca. 1.6 per cent of total employees in Denmark) and close to 80.000 in 2009 (about 2.9 per cent of total employees). Companies in the areas of water, air pollution and chemicals are of comparable size in terms of employees, employing some 21.000 staff in 2005 and close to 40.000 in 2009. Companies operating in the areas of waste and chemicals employ around half of that and relatively few are employed in companies dealing with soil pollution and land use and biodiversity.

Figure 3 Number of Danish EGSS companies and employees by eight environmental areas

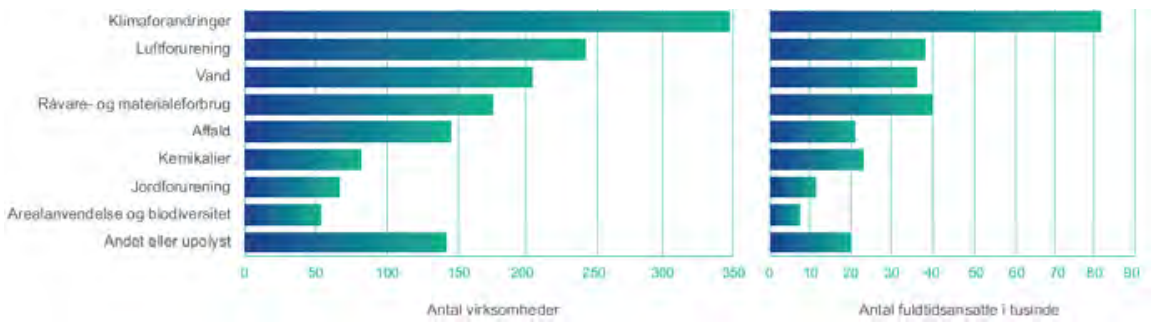

Source: FORA (2009)

The data collection method used did not make it possible to identify the share of employees within each organization that work directly with environmental technologies, hence number of employees should be considered with care.

The EGSS sector belongs to one of the largest sectors in Denmark (FORA 2005). Between 2004 and 2006, the sector experienced an annual 
growth rate of 2,0 per cent in turnover per employee and a 2,2 per cent increase in export per employee (FORA 2006). Companies dealing with water have experienced the largest increase in exports between 2001 and 2006 followed by companies offering goods and services in the area of waste and climate change. Companies working within the area of soil pollution and chemicals have experienced the lowest growth rate in exports within the EGSS sector (FORA 2009). In terms of value added, companies in the waste area have experienced an increase of about 8 per cent per employee between 2001 and 2006, the highest within the sector. Companies operating within the areas of climate change, water, raw materials and consumption of materials have increased value added above the average of the EGSS sector within the same period (more than 4 per cent per employee) (FORA 2009).

\subsubsection{Denmark-summary}

Companies with a business model and ethics based on reducing pressure on the environment were included in the mapping exercise. The criteria set up also stresses the relative impact of the technologies (e.g. products leading to reduced emissions) and it includes reduced impacts on both production and consumption of products. The definition of the EGSS in Denmark was thereby deliberately made broad.

However, there are two obvious challenges in the above set up: first, how to determine what represents "reduced emissions". Reduced emissions only make sense when they are set in relation to a baseline. This baseline necessarily changes over time and is different across countries depending on the geographic endowment (e.g. Iceland has a carbon neutral heating system through the use of geothermal energy) and legislative framework (e.g. Denmark is one of only few countries to charge full costs on water consumption and wastewater treatment). Second, it is problematic to ensure in the mapping exercises that organisations falling within the criteria are actually captured for the whole economy.

Surprisingly, the identification of the environmental challenges which were the basis for defining the areas of activities of companies does not include noise prevention. Noise emissions from e.g. road and air traffic 
are considered a significant source of pollution with clear negative health effects. ${ }^{3}$

Also, focus in the Danish mapping of EGSS has been on enterprises and therefore excludes educational and research activities. Some of these activities are closely intertwined with industry when developing new technologies, measurements and approaches, e.g. DTU Wind Energy.

The mapping exercise did not allow for an indication of the share of employees and turn over that are directly related to the environmental activity and the statistics should therefore be used with precaution. The OECD uses a definition that if 75 per cent of a company's turnover is related to the environment, it may be considered part of the EGSS sector.

\subsection{Finland}

In Finland there is not one commonly used definition of green jobs. The size of environmental and cleantech sectors of the economy have been estimated by ETLA (The Research Institute of the Finnish Economy), Statistics Finland and Cleantech Finland.

\subsubsection{ETLA, The Research Institute of the Finnish Economy}

In 2005, ETLA (The Research Institute of the Finnish Economy), started a project which had the purpose of defining environmental business and to develop better statistical follow-up of the sector. The project aimed to set up a national monitoring system to evaluate the extent of environmental business activities and their international competitiveness. The project introduced a new classification for environmental business clusters and a comprehensive database consisting of 3500 enterprises was constructed (Viitamo and Hernesniemi 2006). A pilot questionnaire survey covering the companies of the database was conducted to evaluate the size and growth of companies in the environmental industry. The definitions and statistics presented in the following sections are based on the report published by the project (Viitamo and Hernesniemi 2006).

The division into business clusters followed mainly the structure used in the Green Pages database directory of environmental companies, ${ }^{4}$ from

\footnotetext{
${ }^{3}$ About $30 \%$ of housing in Denmark is considered exposed to noise pollution from road traffic beyond the limit value of $>58 \mathrm{~dB}$ (Jensen, 2010).

${ }^{4}$ http://www.eco-web.com/
} 
the year 2005, with some amendments. About ten relevant environmental clusters were identified for Finland, and these were further divided into 50 subsectors. The ten main clusters were the following:

- Air protection

- Ecological production and products

- Energy production

- Energy use and energy saving

- Environmental information and data

- Noise prevention

- Recycling

- Soil and landscape protection

- Waste management

- Water management and wastewater treatment

The definition of clusters was tested through a pilot questionnaire, which was sent to 1600 companies in the environmental industry. According to this pilot, the share of companies within the environmental clusters was as described in Table 7.

In the same questionnaire the companies were also asked to define their share of environmental business relative to annual revenue. The estimates were subjective and hence the results have to be considered as such. More than one third of the companies estimated their share of environmental business to be 100 per cent. The larger the company, the smaller was the estimated share of environmental business. Companies with the highest annual revenue estimated the share of environmental business to about 20 per cent. Total size of the environmental business was calculated to 4,2 billion $€$, ca. 2,5 per cent of GDP. Based on the questionnaire a theoretical maximum was calculated for the environmental business in Finland, which was 9,5 billion €. Environmental technology companies were underrepresented, which may influence the estimates notably. 
Table 7 Estimates of environmental industry in Finland

\begin{tabular}{lr}
\hline Sector & Share of companies, per cent \\
\hline Water management and wastewater treatment & 18 \\
Waste management & 16 \\
Environmental information and data & 13 \\
Recycling & 11 \\
Energy production & 10 \\
Soil and landscape protection & 10 \\
Ecological production and products & 10 \\
Energy use and energy saving & 9 \\
Air protection & 3 \\
Noise prevention & 1 \\
\hline
\end{tabular}

Source: Viitamo and Hernesniemi (2006)

\subsubsection{Statistics Finland}

The environmental statistics of Statistics Finland have been recently revised, in December 2011, and they are still being developed further over the next years. The definitions and statistics presented in the following sections are based on the statistics published by the Statistics Finland (www.stat.fi) ${ }^{5}$.

\section{Current definitions used by Statistics Finland}

Environmental business: businesses, which prevent the pollution of the environment and promote the saving of natural resources.

Clean technology (or cleantech): refers to any products, technologies or techniques, and services which cause less damage to the environment or consume fewer natural resources in their production process or use than alternative ones. In terms of the environment, a clean technology product is thus a better product than an alternative product with corresponding characteristics of use. In the production and use of such a product, the average national level may serve as a standard of comparison.

Environmental goods and services sector (see also chapter 2.1): involves production which is based on environmental pollution prevention or the saving of natural resources. Environmental technology is part of environmental goods and services sector. An enterprise which is included in the environmental goods and services sector may have environmental business activity as its main or secondary line of production.

${ }^{5}$ Statistics: Environmental goods and services sector [e-publication]. ISSN=1799-5108. Helsinki: Statistics Finland [referred: 11.12.2011]. Access method: http://www.stat.fi/til/ylt/kas_en.html. 
Environmental goods and services sector is not a specific sector of industry. Instead, production involves several different industry sectors.

Production based on environmental pollution prevention: may include products, technologies or techniques, or services which deal with damage to the air, soil and water, and problems related to waste, noise, biodiversity and natural landscapes. Such production may consist of, or be connected to, activity which involves measuring, monitoring, prevention, treatment, repair, research, development or raising awareness.

Production based on saving natural resources: may include products, technologies or techniques, or services which focus on the saving of natural resources and their effective use either in the production process or utilisation process. Such production may consist of, or be connected to, activity which involves measuring, monitoring, prevention, reduction of use, re-use, recycling, repair, restoration, research, development or awareness raising.

\section{Current statistics}

Environmental statistics are currently in a developmental phase both nationally and internationally. The following statistics are partly based on a survey on environmental goods and services sector (EGSS for Finland, see also chapter 2.1), which was implemented in 2010, as well as statistics of industrial production and financial statement statistics. These statistics have been published now for the second time, but due to the continuing development, not all statistics are comparable with the statistics produced in 2009.

In the current statistics environmental goods and services sector businesses are classified as a main industry or a secondary industry. The difference between these two is that businesses classified as main industry are active in certain predefined environmental sectors, and the sectors are treated as a whole in data collection. Businesses classified as secondary industry may have activities in any sectors, and the share of their environmental activity is estimated through questionnaires.

In 2010, as main industry were considered companies acting in the following branches:

- Production of electricity with hydro or wind power

- Sewerage

- Waste collection, treatment and disposal

- Materials recycling

- Remediation of polluted soil and water and other environmental services 
In 2010, in total 777 companies were classified as main industry and their turnover was estimated to be about 2.4 billion $€$. A third of this comprised of waste management services. It was estimated that about 6630 people were employed within the aforementioned sectors, see Table 8.

Table 8 The main industries in the environmental goods and services sector in Finland 2010

\begin{tabular}{lccccc}
\hline Sector & Companies & Personnel & \multicolumn{2}{c}{ Business activities in mn } \\
& & & Turnover & Exports & Investments \\
\hline $\begin{array}{l}\text { Electricity production with hydro- } \\
\text { and windpower }\end{array}$ & 75 & 473 & 642 & 4 & 136 \\
$\begin{array}{l}\text { Sewage- and wastewater manage- } \\
\text { ment }\end{array}$ & 150 & 379 & 93 & 0 & 17 \\
$\begin{array}{l}\text { Waste collection, handling and end } \\
\text { placement }\end{array}$ & 398 & 4189 & 885 & $4{ }^{1)}$ & 81 \\
$\begin{array}{l}\text { Materials recycling } \\
\text { Soil and waterways renovation and }\end{array}$ & 107 & 1,217 & 745 & 456 & $22^{1)}$ \\
environmental care services & 47 & 372 & 60 & $4{ }^{1)}$ & $3^{1)}$ \\
\begin{tabular}{l} 
Main environmental sectors in total \\
\hline
\end{tabular} & 777 & 6,630 & 2,425 & 469 & 259 \\
\hline
\end{tabular}

Data is very uncertain

Source: http://www.stat.fi/til/ylt/kas_en.html

Companies classified under secondary industries may be active in any sector. Their proportion is estimated through questionnaires. The estimates of secondary industry within the service sector are not yet included in the statistics, but the purpose is to include this in the future as well. In 2012, the size of the secondary industries was estimated from the following sectors:

- Forestry industry

- Chemical industry

- Metal Industry

- Other industry

In 2010 the total turnover of the environmental goods and service sectors within the secondary industries was estimated to 2,1 billion $€$. The metal industry made up about 1 billion $€$ of this. The total number of firms was 266. Out of the total business the environmental business made up about 2 per cent. Environmental business was proportionally largest in the chemicals sector with environmental business contributing to 4 per cent of the total. The largest exporter of environmental goods and services was the metal industry, with a total export of 532 
million euro. See Table 9 and Table 10 for detailed information on the secondary business sectors.

Table 9 The secondary industries in the environmental goods and services sector in Finland 2010

\begin{tabular}{|c|c|c|c|c|c|c|}
\hline & $\begin{array}{r}\text { Companies } \\
\text { active in } \\
\text { environ } \\
\text { mental } \\
\text { business }\end{array}$ & $\begin{array}{r}\text { Total } \\
\text { turnover } \\
(\mathrm{mn} €)^{*}\end{array}$ & $\begin{array}{r}\text { Turnover } \\
\text { within the } \\
\text { environ- } \\
\text { mental } \\
\text { business } \\
(\mathrm{mn} €)\end{array}$ & $\begin{array}{r}\text { Proportion } \\
\text { of environ- } \\
\text { mental } \\
\text { business ( } \\
\text { per cent) }\end{array}$ & $\begin{array}{r}\text { Exports of } \\
\text { environ- } \\
\text { mental } \\
\text { business } \\
(\mathrm{mn})\end{array}$ & $\begin{array}{r}\text { Invest- } \\
\text { ments in } \\
\text { environ- } \\
\text { mental } \\
\text { business } \\
(m n €)\end{array}$ \\
\hline $\begin{array}{l}\text { Forestry } \\
\text { industry }\end{array}$ & 26 & 19,889 & $213^{1)}$ & 1 & $63^{1)}$ & $0,7^{1)}$ \\
\hline $\begin{array}{l}\text { Chemical } \\
\text { industry }\end{array}$ & 50 & 18821 & 832 & 4 & 291 & $23^{1)}$ \\
\hline Metal industry & 170 & 67,689 & 1,039 & 2 & 532 & $79^{1)}$ \\
\hline Other industry & 20 & 18,525 & 56 & 0,3 & 33 & $2^{1)}$ \\
\hline Industry total & 266 & 124,924 & 2,141 & 2 & 919 & $104^{1)}$ \\
\hline
\end{tabular}

Data is very uncertain

Source: http://www.stat.fi/til/ylt/kas_en.html

Table 10 The distribution of environmental business within industry sectors between environmental protection and management of natural resources ${ }^{6}$

\begin{tabular}{lrrrr}
\hline Sector (TOL2008) & Environmental protection & \multicolumn{2}{c}{$\begin{array}{c}\text { Management of environmental } \\
\text { resources }\end{array}$} \\
& $\begin{array}{r}\text { Turnover } \\
\text { (milj. } € \text { ) }\end{array}$ & $\begin{array}{r}\text { Export } \\
\text { (per cent) }\end{array}$ & $\begin{array}{r}\text { Turnover } \\
\text { (milj. } € \text { ) }\end{array}$ & $\begin{array}{r}\text { Exports } \\
\text { (per cent) }\end{array}$ \\
\hline 16-17 Forestry industry & $5^{1)}$ & $0^{1)}$ & $208^{1)}$ & $30^{1)}$ \\
19-22 Chemical industry & 346 & $13^{1)}$ & 486 & 50 \\
24-30,33 Metal industry & $502^{1)}$ & 40 & 538 & $62^{1)}$ \\
$08-15,18,23,31,32$ Other industry & 21 & $29^{1)}$ & 35 & 76 \\
(B och C) Industry total & 873 & 29 & 1,267 & 53 \\
\hline
\end{tabular}

Data is very uncertain

Source: http://www.stat.fi/til/ylt/kas_en.html

${ }^{6}$ Ympäristöliiketoiminta [verkkojulkaisu]. ISSN=1799-4047. Helsinki: Statistics Finland [referred:

13.1.2011]. Access method: http://www.stat.fi/til/ylt/tup.html 


\subsubsection{Cleantech Finland on the cleantech sector and green jobs}

Cleantech Finland is a network of Finnish cleantech companies, which has as its purpose to promote and support cleantech sector companies. Cleantech Finland has conducted a survey on the on the cleantech sector in Finland. The following data is based on this survey as well as an interview of the director of the network 7 .

Cleantech as a sector includes all those products, services, processes and technologies that prevent or reduce the impacts of harmful actions on environment. About 2000 companies are defined as being active in the cleantech sector by Cleantech Finland. The top 100 companies are responsible for about 95 per cent of the total turnover of 18 bill $€$ in the sector. Two thirds of the turnover is estimated to be exports. The sector is estimated to employ about 30.000 people.

The figures of Cleantech Finland include both smaller cleantech firms that have primarily been categorized as cleantech firms and other, larger firms, with production which can only partly be classified as cleantech. Some of the larger firms, that also produce cleantech goods and services (such as Kemira, Metso, Wärtsilä etc.), have estimated a part of their turnover as belonging to the cleantech sector. These companies have in total billions in turnover. This impacts the cleantech statistics and figures ${ }^{8}$.

The larger companies' turnover estimates or the share of business categorized as cleantech are based on the classifications used by OECD for cleantech goods and services. OECD classifies a company as a cleantech company when two thirds of the turnover comes from cleantech related goods and services. This means that for instance Wärtsilä, with a turnover of 4-5 billion, is classified as a cleantech company, and Kemira classifies 75 per cent of their turnover as being cleantech related. The firms themselves provide these estimates. The figures provided by Cleantech Finland do not include the producers and production of energy such as waterpower, bioenergy, wind power etc. or the paper industry, which should be included if the green economy was analysed more broadly. ${ }^{9}$

\footnotetext{
${ }^{7}$ The figures are based on a survey conducted by Cleantech Finland on the cleantech sector in 2011. All of the survey results are not public, but some data has been presented in public

8 This may explain the large difference in the estimates of the turnover, as well as companies, when comparing to the estimates of Statistics Finland (4,5 mrd €, ca. 1000 companies) presented in the previous section. ${ }_{9}^{9}$ Source: Santtu Hulkkonen, Programme Director, Cleantech Finland, 2011
} 


\subsubsection{Finland - summary}

The overview of Finnish studies presented here offer us three estimates of the size of environmental industry in Finland, 4,2 billion $€$ in 2006 by ETLA, 4,5 billion $€$ in 2010 by Statistics Finland and 18 billion $€$ in 2011 by Cleantech Finland. The estimates by ETLA were based on a cluster approach. ETLA considers that the statistics underestimated the size of cleantech companies, whereas Statistics Finland did not yet include businesses from all sectors. For example the service sector is not yet included in the statistics. Cleantech Finland's approach to the estimates was based on quite broad definitions of which proportion of a company's turnover may be considered as cleantech, but even this approach did not include all sectors of the economy.

Several factors contribute to complicate the definitions of environmental industry. Previously only the basic functions such as waste management, recycling and community planning have been classified as specific environmental business according to official statistics and sector classifications. However, many products and services that can be defined as having some type of environmental purpose or which are environmentally less damaging than other comparative products are used or produced in other sectors in addition to traditional environmental business. These should also be accounted for to make consistent statistics. For example, pulp and paper producers may have R\&D sections that develop methods to minimise the environmental impact of paper production. Therefore it is difficult to separate environmental business and production of environmental products and services from other business.

Another complicated issue is how to define where the line between environmentally friendly and non-friendly technology can be drawn. An industry can often be damaging to the environment as a whole even if the technology used is the best available technology (BAT) from an environmental perspective.

The experience from the Finnish estimates reveals two main challenges:

- To identify those companies which have environmental business outside the traditional and obvious fields of environmental management (waste, energy, etc.)

- To estimate, especially within larger companies, which part of their turnover comes from environmental business 


\subsection{Iceland}

Iceland has recently published a comprehensive report on the Green Economy in Iceland, (see Efling graens hagkerfis a Islandi 2011). The report proposes a definition which would make it possible to follow-up strong green sectors and the green jobs in Iceland. It evaluates the state of environmental statistics in Iceland and analyses the need for actions in sectors which are seen as important for the Icelandic economy and in which sustainability is seen to play an important part in the future. The report presents an extensive action plan on how to develop the Icelandic green economy by listing over 40 different actions, by defining the responsible parties for the actions as well as by setting a time line. The report draws from extensive international and domestic sources and it can thus be said that for the purposes of this study it is the most comprehensive and up to date source of information on the green economy in Iceland. The proposals in the report are currently discussed and considered by the Icelandic Parliament.

\subsubsection{Definition used in Iceland}

The report outlines definitions by different international organizations such as the UNEP definition described in chapter 0 . The report concludes that the definition used by the U.S. Department of Labor Statistics, Bureau of Labor Statistics (BLS) would be best suited for Iceland, as this definition is seen to be sufficiently detailed.

It is stated in the report that closer examination reveals that jobs in green industries, as defined by BLS, are not necessarily all in the spirit of all the definitions of the green economy. A look at the working conditions within for instance recycling of electronic devices in Asia reveals that the jobs, which by the BLS definition would be green, could by some definitions be considered unsustainable, for instance by not offering decent working conditions or wages. This point is, however, not seen as crucial for Iceland, domestically. Definitions and classifications by BLS criteria may not be entirely undisputable, but they can, according to the report, be successfully used for classification and economic analysis of the scope of the green industry and green jobs in Iceland. 


\subsubsection{Statistics}

At present reliable estimates of green jobs in Iceland do not exist. Work to strengthen available tools for statistical analysis is currently being done at Statistics Iceland in response to the feedback and requirements of the European Union, the Federation of Icelandic Industries and the ministries. There are plans to develop a register of enterprises within Statistics Iceland, with the aim of providing a permanent foundation for corporate statistics. These statistics will be used to improve national accounts and labour market data, and to monitor and evaluate the production and output of specific sectors (see Ministry of Economic Affairs 2011).

Table 11 gives an overview of the sectors in which people in Iceland were employed in 2010. This table does not, however, give light to the extent of green jobs. The only sector which may be classified as mostly green according to the definitions in chapter 2 is electricity production, which is mostly based on geothermal and hydro power production.

\begin{tabular}{lrr} 
Table $\mathbf{1 1}$ Employment by activity in $\mathbf{2 0 1 0}$ & \\
\hline Estimated Number & Number $\mathbf{2 0 1 0}$ & Per cent 2010 \\
\hline Agriculture & 4,700 & 2.8 \\
Fishing & 5,000 & 3.0 \\
Fish processing & 3,600 & 2.2 \\
Manufacturing except fish processing & 15,400 & 9.2 \\
Electricity and water supply & 1,500 & 0.9 \\
Construction & 10,500 & 6.3 \\
Wholesale, retail trade, repairs & 20,600 & 12.3 \\
Hotels, restaurants & 8,000 & 4.8 \\
Transport, communication & 10,800 & 6.4 \\
Financial intermediation & 8,000 & 4.8 \\
Real estate \& business activities & 17,500 & 10.4 \\
Public administration & 8,600 & 5.1 \\
Education & 20,500 & 12.2 \\
Health services, social work & 28,200 & 16.9 \\
Other services & 4,500 & 2.7 \\
\hline
\end{tabular}

Source: www.statice.is

The most important "green" sectors in Iceland mentioned in the report are the energy sector, cleantech sector (including ocean cluster cleantech), the fishing industry (though not classified as a green sector according to $\mathrm{Bu}$ reau of Labour Statistics criteria, but could be possibly partly include some green jobs in the future, as sustainable fishing and green fishing technology develops), organic farming and eco-tourism. The potentially 
green sectors in Iceland were presented as examples of areas of importance for Iceland, not as a comprehensive list of green sectors.

A list of the most important potential green sectors in Iceland could, thus, look like the following: ${ }^{10}$

- energy - geothermal and hydropower production as well as energy efficiency

- green technology - the ocean cluster with sustainable fishery and fishing techniques and technologies may be a part of this in the future

- waste management and recycling

- organic farming

- sustainable tourism

In the following sections some facts related to green sectors as defined in the framework chapter 2 are presented.

Renewable energy: Electricity and water supply employs close to 1.600 people according to Statistics Iceland. The jobs within the electricity supply sector can be considered green jobs as the electricity production of Iceland consists almost entirely of geothermal energy and hydropower. In 2008 roughly 82 per cent of primary energy was derived from indigenous renewable sources (62 per cent geothermal, 20 per cent hydropower). The rest of Iceland's energy sources came from imported fossil fuel used for fishing and transportation.

Agricultural production: Today a very small proportion of agricultural production is organic. Organic farming is estimated to be about 2 per cent of the total production. The agricultural sector employed about 4700 people in 2010. Thus a very small proportion of them could be considered as having a green job. In this sector growing demand for organic production is foreseen and thus some of the workforce will as a result turn greener.

Fishing industry: Fishing is a very important part of the Icelandic economy, even though the sector has contracted in the previous decades. The fishing and fish treatment industry employs in total over 8500 people in Iceland.

As such the fishing industry is not considered a green sector as defined by BLS criteria. But within the sector, as well as sectors linked with it, there are some green jobs. Green jobs in the fishing industry can ex-

${ }^{10}$ Interview with Stefan Gislason, Environice 12.01.2012 
tend to sustainable fisheries management, the use of environmentfriendly energy sources in fishing, energy conservation, development of environmental fishing gear, using fishing by products for biotech production and so forth. Statistics on the extent of green jobs within this sector do not, however, as yet exist.

The Icelandic Ocean Cluster has mapped the ocean related technology sector in Iceland. The mapping of the ocean related technology sector has indicated that the technology sector is made up of over 70 firms, mostly small technology driven firms, which have their own tech brands and export to other countries. However, the proportion of these, which could be classified as being ocean cluster related cleantech companies, is not known. The ocean cluster has also mapped emerging niche areas (e.g. eco-ocean tourism, marine renewable energy, marine biotechnology, green technology, etc.). The mapping is at a finalizing stage and may, perhaps, bring more light to the matter. ${ }^{11}$

Several companies have specialized in services and/or development and production of tools and equipment, which are directly designed to reduce pollution and other negative impacts on the environment. There are employees working in such jobs in companies within both more and less polluting sectors. However the numbers have not been specified as yet.

\subsubsection{Summary - Iceland}

At present there is a lack of statistics for green jobs and sectors in Iceland. There are however plans to improve statistical follow-up of green sectors and jobs. The recently published report by the Parliamentary committee on the development of the green economy (Efling graens hagkerfis a Islandi 2011) has addressed many of the issues of how to define, develop and monitor the development of the sk. green sectors and jobs. The definition which has been proposed to be used is the one used by the US Bureau of Labour Statistics, described in chapter 2. The report is currently under discussion by the parliament.

${ }^{11}$ Iceland Chamber of commerce, www.vi.is 


\subsection{Norway}

\subsubsection{The National Strategy for Environmental Technologies}

The Norwegian government launched a strategy for business development and green growth, i.e. environmental technology (Ministry of environment 2011). This strategy is developed based on the work of a strategic assembly for environmental technology consisting of members from relevant ministries, businesses, research institutes, regional administrations, labour organisations and environmental NGOs. The purpose of the strategy is both to promote business development and to contribute to reaching environmental goals. The vision is that Norway shall become a central supplier of environmental technologies.

The strategy defines environmental technologies as technologies that, directly or indirectly, improve the environment. This includes technologies that reduce pollution by cleansing devices, more environmentally friendly products and production processes, more efficient resource use and technological systems that reduce the environmental burden. The term technology includes knowledge/competence, services and physical devices.

There are several measures for promoting green technologies, administered through several governmental agencies, like Innovation Norway (the so called environmental technology agreement for commercialisation of new technologies), Enova (support to renewable energy), Transnova (transport related technologies) and the research council (NFR, both through specific programmes and independent projects). In 2011 a new three-year program for environmental technologies was established, targeted towards commercialisation of new and green technologies, and verification and testing of such technologies.

However, there are no official statistics covering the activities of companies working with environmental technologies, mainly due to the broad definition of environmental technology including many sectors. In the 2011 strategy this is discussed, with references to the work in OECD on green growth, and one of the goals stated in the strategy is to develop indicators for green growth and to arrange for better measurement of the performance in the relevant business sectors. The national strategy presents no figures for employment or alike for the environmental technology sectors and business, neither present figures nor estimates for future development. 
Although official statistics are lacking, there are a couple of studies that have estimated the size of the environmental technology sector in Norway, the employment potential and the "greenness" of Norwegian companies in general. Below is briefly referred some of the studies and their findings.

\subsubsection{A knowledge based Norway}

As a part of the research project "A knowledge based Norway" headed by BI Norwegian School of Management. Menon Business Economics conducted a survey of the renewable energy and environmental technology sector in Norway estimating the size of these sectors, see Grünfeld and Espelien (2011).

Grünfeld and Espelien (2011) divide the clean energy and environmental sectors in 11 segments, covering renewable energy (hydro power; bioenergy; wind power; solar energy; other), environmental technology and services (consultancy, R\&D, ICT and finance; energy efficiency; cleaning of emissions from industry and transport; environmental monitoring), traditional environmental business (waste management) and power distribution and trading. According to Menon they have applied a rather strict definition of relevant businesses, in order not to include normal technological development towards more efficient products.

All companies that are included in the sectors as defined by Menon are given an environmental weight describing how much of the total activity that is actually related to environmental technologies. This is particularly important for large enterprises like Statoil, where clean energy constitute a marginal part of total activity. Including the total activity of Statoil would give directly misleading results.

Based on their own business database Menon mapped employment etc for a total of 2.210 companies within the defined sector. The findings in Grünfeld and Espelien (2011) are summarized in Table 12. 
Table 12 Clean energy and environmental business sector, 2009

\begin{tabular}{lrrr}
\hline Sector & $\begin{array}{r}\text { Number of } \\
\text { companies }\end{array}$ & $\begin{array}{r}\text { Value added } \\
\text { MNOK }\end{array}$ & $\begin{array}{r}\text { Number of } \\
\text { employees }\end{array}$ \\
\hline Renewable energy & 1,164 & 35,790 & 18,047 \\
Hydro power & 779 & 32,094 & 10,897 \\
Bio energy & 238 & 994 & 2,350 \\
Wind power & 78 & 407 & 848 \\
Solar energy & 41 & 1,610 & 3,613 \\
Other clean energy & 28 & 685 & 339 \\
Environmental technology and services & 220 & 4,725 & 7,991 \\
Consultancy, R\&D, ICT and finance & 91 & 2,926 & 5,818 \\
Energy efficiency; & 77 & 1,287 & 1,506 \\
Cleaning of emissions from industry and transport & 39 & 369 & 418 \\
Environmental monitoring & 13 & 143 & 248 \\
Traditional environmental business (waste management) & 571 & 6,475 & 9,352 \\
Power distribution and trading & 255 & 12,967 & 9,556 \\
Total & 2,210 & 59,957 & 44,946 \\
\hline
\end{tabular}

${ }^{1}$ Wage expenditure/450,000 NOK

Source: Grünfeld and Espelien (2011)

The strongest growth in the 11 sectors has been in solar power, with an average yearly growth in sales of 86 per cent between 2003 and 2009 . This illustrates that the largest growth has been in new sectors, and not in mature sectors like hydro power. When analysing these figures it is important to take account of the low starting level for the new sectors like solar power, and in addition the companies included in the statistics has been selected manually in 2007/2008 and this selection can be biased towards successful companies. A selection based on NACE would also include less successful companies, and hence most likely show lower average growth rates.

\subsubsection{Tekna: Green economy Norway}

In 2009 Tekna (The Norwegian Society of Graduate Technical and Scientific Professionals) presented a report about the potential for a green economy in Norway, see Econ Pöyry (2009). The background for the report was the emerging financial crisis, and the possibility to use the measures to limit the effects of the crisis to support the development of green, or environmental friendly, technologies. It was also based on the UNEPs Global Green New Deal-initiative, and an ambition to present a land report for Norway.

The report uses official statistics to identify the environmental pressure from different sectors, for instance the CO2-intensity. But for socalled "green sectors" the report only present figures from single industries or sectors. As an example companies providing equipment to the 
wind power industry employed a bit over 1,000 persons in 2007, constituting an increase of 185 per cent since 2004.12,13

Based on several studies of the employment potential in different sectors Econ Pöyry (2009) estimates how much employment the Norwegian goals for different energy technologies could generate in 2016, see Table 13.

Table 13 Employment potential of different measures, 2016

\begin{tabular}{lcr}
\hline Technology & Goal 2016, TWh & Estimated man-labour years \\
\hline Wind power & 6 & $1,900-6,000$ \\
Heating technologies (bio energy) & 8 & $400-3,200$ \\
Energy efficiency & 2,4 & $26,000-40,000$ \\
Hydro power (potential, no goal) & $4(2020)$ & $800-1,250$ \\
Total & & $29,100-50,450$ \\
\hline
\end{tabular}

Source: Econ Pöyry (2009)

Common to all the potentials presented in Table 13, is that they most likely are dependent on a strong expertise in science and technology. A shift to an economy with reduced emissions of greenhouse gas emissions and increased energy efficiency requires that new technologies are introduced and used effectively, and that new technologies are developed and improved. Technological competence is thus crucial, and Econ Pöyry (2009) points to the need for competence development in order to increase the number of technical and scientific expertise.

\subsubsection{Statistics Norway}

In 2008 Statistics Norway performed a pilot project where the purpose was to find a definition of an environmental sector that could be used as a statistic subject, see Smith (2008). In the project various issues related to establishing such statistics in Norway was investigated. A case study was conducted for the manufacturers of water, sewage and sludge treatment technologies. These technologies included 31 firms with a total of 321 employees. 74 per cent of the firms were small businesses with less than 20 employees. 25 of the 31 firms had production of environmental technology as their main activity. It was mainly larger companies where environmental technology was a secondary activity.

12 http://www.vindkraft.no/ny_naring/

13 Fornybar Energi (2007) 
In 2006 the turnover for the identified firm was 777 MNOK, an increase of 6.6 per cent from the previous year. Adjusted for exports (313 MNOK), the domestic market equalled 464 MNOK in 2006. With a total import of equipment for filtering and purifying of water of 164 MNOK, Smith (2008) estimates that the domestic market for such technologies is at least 628 MNOK. Using other data investment in the water supply, municipal sewage and wastewater treatment industry is estimated to be approximately one billion. According to Smith (2008) there are probably two main explanations for the gap between revenues and investment in treatment technology: 1) some costs associated with the construction of treatment plants and other installation work are not attributable to environmental technology, 2) some large enterprises, where only a small part of total activity is related to environmental protection, are excluded if this part cannot be identified. The latter is done to prevent that the statistics are completely dominated by such large firms.

The pilot project investigated significant issues related to mapping the environmental industry in Norway. The method used in the case study involved extended contact with the firms, both written and verbally. Such thorough contact is normally not given priority in the production of statistics, and the method is most likely too costly to be used for regular statistics about environmental industries. However, such qualitative studies can be useful when establishing new statistics. Moreover, such a procedure is important as a test of the difference between the estimated figures based on less resource-intensive methods and real numbers based on detailed data collection.

Smith (2008) recommends that one make use of secondary sources such as internet, annual reports, etc. to define populations for different environmental areas. These sources can also be used as primary sources to estimate the firms' environmental interest. Establishing a database of environmental companies could also form a basis for such statistics. 


\subsubsection{Elektro-forum}

In 2010 The Elektroforum Foundation ${ }^{14}$ commissioned Pöyry and Thema Consulting Group to perform an assessment of green business opportunities, see Pöyry (2010).

In this report green business sectors are defined as economic activity that contributes to a) more efficient use of scarce natural resources, b) reduced emissions, or c) better cleaning, see also Table 14. This is a broad definition, including both energy and other natural resources.

\begin{tabular}{|c|c|c|c|}
\hline & Increased efficiency & Reduced emissions & Better cleaning \\
\hline Through & reduced resource intensity & $\begin{array}{l}\text { better and new processes, } \\
\text { technology and products }\end{array}$ & $\begin{array}{l}\text { better cleaning methods } \\
\text { and waste treatment }\end{array}$ \\
\hline General & $\begin{array}{l}\text { Reduced use of energy and } \\
\text { other scarce resources, } \\
\text { without compromising the } \\
\text { welfare }\end{array}$ & $\begin{array}{l}\text { Develop product and } \\
\text { processes that are part of } \\
\text { a circular flow }\end{array}$ & $\begin{array}{l}\text { Treatment of waste that } \\
\text { are not compromising the } \\
\text { sustainability }\end{array}$ \\
\hline Energy sector & Energy efficiency in all sectors & $\begin{array}{l}\text { Conversion from fossil } \\
\text { fuels to renewable energy }\end{array}$ & CCS \\
\hline
\end{tabular}

Source: Pöyry (2010)

Pöyry (2010) distinguish between inner and outer sectors, where the inner sectors include activities that directly contribute to the fulfilling of the mentioned goals. This includes for instance renewable energy production and enterprises implementing energy efficient solutions. The outer sectors include economic activities that are increasing due to structural changes in the economy, but where the main target is not to be "green". Examples of such activities are aluminium production which experience an increased demand as aluminium substitutes for steel to give an environmental benefit. Over time activities in the outer sector can move towards inner sectors.

The report also discusses the divide between green and other sectors, and if it is relevant to have such a divide. They argue, however, that it in a transition period with a substantial readjustment need (like today), it will be of both political and commercial interest to understand which markets that are likely to grow and decline as a result of the structural changes.

14 The Elektroforum Foundation is established by 6 trade organisations: The Electro Associtaion, Federation of Norwegian Industries, The Industry's Association for Electrotechnics and Automation (IFEA), The Organisation for Electro and IT Enterprises (NELFO), Energy Norway and Association of Consulting Engineers (RIF) 


\subsubsection{Summary-Norway}

In Norway there has, so far, been little to establish EGSS statistics. For official statistics the same challenges as reported for the other countries, i.e. how to divide between green and non-green industries and sectors and the resource needed to establish the statistics, are identified.

The work that has been done is mainly commenced and financed by different industry organisations. For such organisations a mapping of potentials can be useful as it might help their members to position themselves for an anticipated increased demand for such technologies.

\subsection{Sweden}

\subsubsection{Statistics Sweden}

Already in the late 1990's Statistics Sweden started to collect data for the environmental goods and services sector, and has more or less worked continuously with this since then. Thereby Sweden was one of the first countries to develop and use EGSS statistics.

Statistics Sweden uses the same definition of EGSS as OECD/EU, i.e. "environmental goods and services industry consists of activities to measure, prevent, limit, minimise or correct environmental damage to water, air and soil, as well as problems related to waste, noise and ecosystems. This includes cleaner technologies, products and services that reduce environmental risk and minimise pollution and resource use" (Brolinson et al. 2006).

In 1998, Statistics Sweden established a database containing enterprises and their establishments active in the EGSS. The database consists of individual producers of environmental goods and services, being used and combined with existing registers and surveys. This way a lot of detailed information can be produced without the need to introduce new surveys. The database is built up using a three step method:

1. Identification of the population

2. Classification

3. Adding supplementary information

The main task of the first phase of the work was to establish a first preliminary database of environmental enterprises, and to investigate what could be used from existing registers and surveys. Data were first presented for the so-called "core industries", i.e. industries (NACE groups) 
which are deemed to be included entirely under the definition of environment industry, see for instance Tängden et al. (2000). Several sources were being used in this work, for instance Internet, the Swedish business register, different enterprise databases and information from relevant business organisations. Continued work focused mainly on improving the database, both as regards coverage and detail. At this stage enterprises in the database were classified according to how important the environmental activity was (primary, secondary, etc.) and what the primary environmental activity was.

At present new establishments are automatically transferred from the business register for core industries (using the SNI 2007 codes) twice every year. In addition new sectors and new establishments that are not part of the core industries are manually updated yearly.

In later years there has been several method projects with the aim to improve to EGSS statistics, for instance by introducing a product perspective (Brolinson et al., 2006) and a supply chain perspective (Eberhardson and Wadeskog, 2010). However, so far only figures for environmental establishments (or working places) are being published regularly.

The latest figures for the EGSS show that in 2010 the turnover in this sector was 230,000 MSEK, with a total export of 35,000 MSEK equalling 2 per cent of total Swedish export. For most years since 2003 both turnover and export in EGSS has showed a larger growth than for all the economy (scb, 2011). In 2009 the sector constituted about 15.000 establishments, and employed almost 70,000.

\subsubsection{Summary - Sweden}

Sweden has been in the forefront in the development of EGSS statistics, and at least since 2003 these statistics are being published on a yearly basis. There has been a continuously development of these statistics, which earlier caused difficulties when comparing the development from one year to another. Historic data are being re-established when new environmental establishments have been identified, and hence the figures for different years are comparable.

There are no figures for the total resources used for the development of these statistics, but obviously Sweden has put a lot of resources and effort in this work. During the work Statistics Sweden has established routines and databases that today are less resource demanding to maintain and update on a regularly basis. 



\section{Future production and employment pattern}

\subsection{Denmark}

In Denmark, the Ministry of Finance produces long-term forecasts of the Danish Economy for use in the development of long-term finance policy. The latest official macro-economic forecast dates from 2007 as basis for the Plan 2015 (Danish Ministry of Finance 2007). The present report has been granted access to a more recent forecast, which was used by the Danish Energy Agency to predict emissions in their Energy Strategy 2050 (Regeringen, 2011).

The forecast is based on the aggregated model ADAM (Annual Danish Aggregated Model), developed by Statistics Denmark. Table 15 below shows projections of gross production by main economic sector.

\begin{tabular}{lrrrr} 
Table $\mathbf{1 5}$ Economic activity in Denmark, share of gross production value by main sector. Per cent \\
\hline Sectors & $\mathbf{2 0 0 0}$ & $\mathbf{2 0 1 0}$ & $\mathbf{2 0 2 0}$ & $\mathbf{2 0 3 0}$ \\
\hline Total Production & 100 & 100 & 100 & 100 \\
Production of goods & 25 & 22 & 22 & 23 \\
Service Sector & 42 & 48 & 51 & 52 \\
Public sector services & 15 & 16 & 13 & 13 \\
Agriculture & 3 & 3 & 3 & 3 \\
Energy production & 2 & 1 & 6 & 1 \\
Construction sector & 7 & 6 & 5 & 6 \\
Use of housing & 5 & 5 & & 5 \\
\hline
\end{tabular}

Source: Danish Ministry of Finance (2011)

The share of renewable energy of total gross energy consumption is predicted to increase by close to 10 percentage points over a 20 -year period (see Table 16) while total production over the same period (2010-2030) is forecasted to increase by 43 per cent (based on 2000 prices). This combined with the position as the country in Europe with the second lowest energy consumption in relation to GDP (after Iceland) indicates a continued effort to greening the economy. 
Table 16 Predicted share of renewable energy (percentage annual share)

\begin{tabular}{lrrr}
\hline & $\mathbf{2 0 1 0}$ & $\mathbf{2 0 2 0}$ & $\mathbf{2 0 3 0}$ \\
\hline Gross energy consumption (DK) & 19.7 & 26.4 & 28.8 \\
Extended final energy consumption (EU) & 21.1 & 27.9 & 30.8 \\
Transport energy consumption & 1.0 & 6.0 & n.a. \\
\hline
\end{tabular}

Source: Danish Energy Agency (2011)

\subsection{Finland}

In 2010, the Government Institute for Economic Research published a report (Needs for workforce in the Finnish Economy 2010-2025, 2010) providing a forecast for the demand of labour in Finland (Government Institute for Economic Research, VATT 2010). The study uses VATTAGE, a dynamic, applied general equilibrium model of the Finnish economy, to forecast structural changes in the Finnish economy up to the year 2025. The study is the first of its kind for a European country and is intended to provide the basis for the policy development by several ministries. According to the forecast (see Table 17, industrial production, finance, primary production and energy will decrease slightly, whereas social services, healthcare and construction and commerce will increase. Much of this development is due to the ageing population. A similar study published by the Finnish National Board of Education has reached similar conclusions, although that study includes also an alternative scenario, where the economy is expected to have stronger growth, and in that case the industrial production is considered to grow as well (Hanhijoki et al. 2009).

Table 17 Economic and employment structure in Finland, forecast 2010-2025

\begin{tabular}{lrrrr}
\hline Sector & $\begin{array}{c}\text { Economic structure } \\
\text { \% of total value added }\end{array}$ & \multicolumn{2}{c}{$\begin{array}{c}\text { Employment structure } \\
\text { \% of total employment }\end{array}$} \\
& $\mathbf{2 0 0 5}$ & $\mathbf{2 0 2 5}$ & $\mathbf{2 0 0 5}$ & $\mathbf{2 0 2 5}$ \\
\hline Energy & 2.0 & 1.3 & 0.5 & 0.4 \\
Construction, commerce and transport & 30.9 & 32.6 & 31.5 & 33.2 \\
Other public services & 3.9 & 4.6 & 5.2 & 4.9 \\
Social services & 4.4 & 5.1 & 7.5 & 10.4 \\
Health care & 5.7 & 6.8 & 7.1 & 9.8 \\
Public administration and defence & 11.6 & 11.8 & 14.3 & 14.5 \\
Finance and business sector services & 18.4 & 16.9 & 10.5 & 10.1 \\
Industrial production & 18.1 & 17.6 & 18.0 & 12.4 \\
Primary production & 4.0 & 3.3 & 5.3 & 4.4 \\
\hline
\end{tabular}

Source: Government Institute for Economic Research 
Regarding green sectors, no national- level estimates have been published on the growth possibilities in the future. Cleantech Finland has published some estimates regarding the annual growth expectation of the cleantech sector in Finland, based on survey data from cleantech companies. According to Cleantech Finland the yearly growth of the sector is estimated to have been about 5-10 per cent yearly since the end of the 1990s. The cleantech-market grew at a rate of 5.6 per cent from 2009 to 2010. The growth expectation for 2011 is 9.6 per cent. Almost half of the turnover comes from the energy efficiency related sector. In the next few years the greatest growth is expected to come from the production and distribution of renewable energy. Energy efficiency, water management, waste management and recycling are also estimated to grow. 15

The most important market areas for Finnish Cleantech companies in Europe have been Germany, Sweden and the domestic market in Finland. The rapidly rising export countries are China, India and Russia, with China as the clear number one. It can be estimated that about two thirds of cleantech sector goods and services are exported ${ }^{16}$. Finland is a leading cleantech expert in certain sectors. Some of the sectors where cleantech expertise is strong at present, according to Cleantech Finland, are energy, materials- and water efficiency, clean industrial processes, bio-energy, bio-fuels and combined heat- and electricity production as well as measuring and monitoring. ${ }^{17}$

The Environmental Forum of the Confederation of Finnish Industries $^{18}$ has also listed the green sectors of Finnish economy that would be strong candidates for growth in the future. These are bio-economy, water management, clean food production, sustainable metals and minerals, energy efficient machines and devices, smart grids, electric vehicle technology, sustainable urban construction and eco-tourism.

\footnotetext{
15 The figures are based on a survey conducted by Cleantech Finland on the cleantech sector in 2011. All of the survey results are not public, but some data has been presented in seminars.

16 Discussion with Santtu Hulkkonen, Program Director of Cleantech Finland, 2011

17 The figures are based on a survey conducted by Cleantech Finland on the cleantech sector in 2011. All of

the survey results are not public, but some data has been presented in seminars.

18 Confederation of Finnish Industries, Environmental Forum

http://www.ek.fi/ymparistofoorumi/fi/tietoa_alasta/suomi_ymparistoliiketoim.php visited 15.1.2012
} 


\subsection{Iceland}

At present there are no reliable official forecasts available for the future economic development and employment structures in Iceland. As to the development of green sectors in Iceland, the parliamentary report on the green economy (Efling graens hagkerfis a Islandi, 2011) discusses some sectors which are seen to be of importance for the development of the green economy. These sectors can't all be considered as green sectors, but are the sectors within which so called green jobs may develop given favourable conditions.

\section{Fishing industry}

Although as such the fishing industry is not considered a green sector, but within the sector, as well as sectors linked with it, there are some jobs that can be defined green, in for instance development of sustainable fishing. Still more may arise if conditions are favourable. Green jobs in the fishing industry could extend to sustainable fisheries management, use of environment-friendly energy sources in fishing, energy conservation, development of environmentally less damaging fishing gear and so forth. Significant opportunities for economic development and value creation are seen to exist in the full use of marine resources. This includes the processing of proteins, leather industry, wound plaster from cod skin (biotechnology) etc.

\section{The ocean cluster}

The cluster in itself cannot be considered green, but in the mapping of the cluster in 2011 some potential green niche areas, where growth could be foreseen, were identified. Given the importance of the ocean cluster for the Icelandic economy it is therefore included in this section. The mapping of the ocean related technology sector has indicated that the technology sector is made up of over 70 firms, mostly small technology driven firms with exports. The ocean cluster has mapped emerging environmental niche areas (e.g. eco-ocean tourism, marine renewable energy, marine biotechnology, green technology, etc.). The mapping is at a finalizing stage (see Icelandic Chamber of Commerce, www.is.fi)

\section{Renewable energy}

The jobs within the energy sector can be considered green jobs, at least according to the BLS definition, as the energy production of Iceland consists almost entirely of geothermal energy and hydropower. According to an evaluation of electricity generation made in $2009,15-18$ per cent of the potential electricity generation capacity of geothermal heat has 
been harnessed. It is believed that in the next 15 years, it will be possible to double the current level of electricity generation in Iceland. An increase of about 10,000-12,000 GWh of geothermal and 4,000-5,000 GWh in hydropower are considered likely. Those plans indicate that there will be a strong need for geothermal technology knowledge in Iceland in the coming years; in addition, special opportunities will arise within the development of Icelandic geothermal energy utilization (see Gunnarsson and Porgeirsdóttir 2011) This will likely generate new green jobs.

\section{Agricultural production}

The Parliamentary committee on the development of the green economy has proposed that organically certified products should make up 15 per cent of agricultural production in the year 2020. Today a very small proportion of the production is organic. The increased demand has already led to some new jobs created in organic production. One obstacle to tackle is to meet the demand for organic fertilizers for farming.

\subsection{Norway}

In Norway the Ministry of Finance conducts long-term forecasts for the Norwegian economy every fourth year, and the latest forecast was published in 2009 (Norwegian Ministry of Finance, 2009). This report describes the framework and challenges for a sustainable development in Norway. The report sets up a 10 point strategy: further development of the Norwegian (Scandinavian) economic model; working for strong global institutions; investments in human resources; develop the working capacity and motivate to increased work contribution; investments in infrastructure; more efficient economy/markets; reforming the public sector; a comprehensive industrial policy; increased focus on maintenance instead of repairs, especially of human resources; and Norway as a forerunner globally with respect to environmental and climate policy. Several of these points are relevant for the transition towards a greener economy, but it is especially the last point that is important. According to this strategy Norway should implement an offensive national environmental and climate policy, partly through strong and focused support to R\&D in new climate friendly technologies.

The long-term plan includes an economic forecast up to 2060. The forecast is based on the macroeconomic model MSG (Multi Sectoral Growth model), developed and maintained by Statistics Norway (see e.g. Heide et al. 2004). The estimated trend follows the historical develop- 
ment towards increased employment in the service sector, and decreased employment in industrial production. In Norway a large part of the increased employment in services are due to an increase in the public sector. A part of the explanation is an ageing population, and an increased demand of care and health services. The estimated composition of economic activity towards 2060 is presented in table 7.1. The grouping of sectors in this projection is too rough for it to be able to say anything about the future employment pattern, except the above mentioned transition from production of goods to production of services.

Increased employment share in the public service correspond to a decreased employment share in private sector, and mainly in production of goods. Due to increased productivity the gross production in mainland enterprises increase its share of total value added. This is partly due to an increase in private consumption and that services will constitute an increasing part of this consumption when the total wealth increases.

It is important to take into consideration that the projection of the future sector composition has a high degree of uncertainty.

Table 18 Economic activity in Norway, man-hours and share of man-hours and gross production value by sector. Per cent

\begin{tabular}{lrrrrrr} 
& \multicolumn{3}{c}{ Man-hours } & \multicolumn{3}{c}{ Gross production value $^{\mathbf{1}}$} \\
& $\mathbf{1 9 7 0}$ & $\mathbf{2 0 0 7}$ & $\mathbf{2 0 6 0}$ & $\mathbf{1 9 7 0}$ & $\mathbf{2 0 0 7}$ & $\mathbf{2 0 6 0}$ \\
\hline Mainland Norway & 100,0 & 100,0 & 100,0 & 100,0 & 100,0 & 100,0 \\
Production of goods & 48.7 & 26.9 & 19.1 & 41.0 & 25.8 & 25.0 \\
Primary sector & 15.9 & 4.2 & 1.1 & 3.4 & 2.5 & 1.3 \\
Power supply & 0.9 & 0.5 & 0.2 & 2.8 & 3.1 & 1.1 \\
Industry & 23.9 & 13.5 & 12.3 & 26.7 & 14.7 & 17.0 \\
Construction sector & 8.0 & 8.7 & 5.5 & 8.0 & 5.4 & 5.6 \\
Service sector & 51.3 & 73.1 & 80.9 & 59.0 & 74.2 & 75.0 \\
Housing services & 0.0 & 0.0 & 0.0 & 8.2 & 5.6 & 6.8 \\
Private service sector, other & 35.1 & 46.4 & 46.2 & 29.0 & 47.2 & 54.3 \\
Public sector services & 16.2 & 26.7 & 34.7 & 21.8 & 21.4 & 13.8 \\
\hline
\end{tabular}

${ }^{1}$ Excl. of fees and duties. Fixed 2004 NOK.

Source: Norwegian Ministry of Finance (2009).

\section{Sectoral studies}

In addition to the above mentioned macroeconomic projection there are some studies that discuss future potential of environmentally friendly (or green) technologies. These studies typically have a shorter time horizon than the long-term planning projections.

Pöyry (2010) refers to international studies showing that investments in green sectors are estimated to be around 1 per cent of global GDP, and that the growth rate will be well above the economy as such. Using the same assumptions for the Norwegian economy Pöyry (2010) 
estimates investments in green value chains to be around 30 billion NOK in 2010, increasing to 45 to 55 billion NOK in 2020.

\subsection{Sweden}

Every third year, long term surveys for the Swedish economy are being presented, the last one being The Long-Term Survey 2011 (SOU, 2011). This survey focuses on the labour market, and how to assure a wellfunctioning and efficient market. It also discusses the educational system, and how to link the choice of education and the needs of the labour market (how to match the need for and the supply of skilled labour), see chapter 7. However, for our purpose the survey from 2008 is more interesting, see SOU (2008).

The Long-Term Survey 2008 includes amongst other a prediction of long-term economic development up to 2030, with a rather detailed assessment of the development of the production structure. Changes in man-hours and productivity in the so called base case for some sectors are summarised in Table 19. The structural change, with an increasing service sector, will continue, and will be accompanied with a decrease in working hours in manufacturing industries and primary sectors. The fastest growth is expected in personal services, retail and wholesale and the construction sector.

The growth in productivity is expected to continue to be high in manufacturing industries, but with a slightly slower rate than historically. It is especially in the electronic and optic sector that the growth rate will be lower than the exceptionally high rate since mid-1990.

The growth in productivity is partly explained by an increase in the educational level among the work force. In the base case it is expected that the share with post upper secondary education will increase with 10 per cent from 2005 to 2030 . 
Table 19 Growth in man-hours and productivity in some sectors 1980-2030, yearly percentage change

Sector

1980-2005 Produc- 2005-2030 Produc-

\begin{tabular}{lrrrrr} 
& Man-hours & tivity & Man-hours & tivity \\
\hline Primary sectors & -2.7 & 2.9 & -3.2 & 4.0
\end{tabular}

Manufacturing industries

$\begin{array}{rrrr}-2.7 & 2.9 & -3.2 & 4.0 \\ -0.8 & 4.4 & -0.6 & 3.8 \\ -0.2 & 7.3 & -2.3 & 0.4 \\ -1.0 & 1.8 & -0.1 & 1.2 \\ -0.1 & 1.3 & 0.7 & 0.9 \\ 0.2 & 3.2 & 0.7 & 2.6 \\ -0.5 & 1.8 & -0.4 & 2.8 \\ 1.0 & 6.0 & -0.7 & 4.1 \\ 3.4 & -1.7 & -0.7 & 2.6 \\ 2.1 & -0.2 & 0.7 & 1.0 \\ 0.3 & 2.5 & 0.9 & 0.7 \\ & & 0.1 & 2.3\end{array}$

Coke, petroleum products

Power, gas, heat, water and treatment

Construction sector

Retail and wholesale

Transport, warehouse

Communication

Finance and insurance

Housing services

Personal services, education, health care, hotel and rest.

Total

Source: SOU (2008).

Changing productivity growth and demand will result in structural changes, see Table 20 .

Table 20 Structural changes in industrial sector 2005-2030, per cent.

\begin{tabular}{lrrrr}
\hline Sector & $\begin{array}{r}\mathbf{2 0 0 5} \\
\text { Value added }\end{array}$ & $\begin{array}{r}\text { Man-hours } \\
\text { Value added }\end{array}$ & Man-hours \\
\hline Primary sectors & 2.3 & 4.4 & 1.5 & 1.9 \\
Mining, minerals & 0.2 & 0.3 & 0.3 & 0.2 \\
Manufacturing industries & 30.7 & 25.1 & 35.8 & 20.8 \\
Power, heat, water & 2.6 & 1.1 & 1.9 & 1.0 \\
Construction & 4.7 & 8.9 & 3.8 & 10.3 \\
Services & 59.4 & 60.2 & 56.8 & 65.8 \\
Total & 100 & 100 & 100 & 100 \\
\hline
\end{tabular}

Source: SOU (2008). 


\section{Future competence needs}

Generally there has been a growth in the demand for labour with high skills and educational levels over the past decades, as a consequence of increased globalisations and technological progress, see for instance Bjørnstad et al. (2010). This trend is likely to continue, regardless of technologies in focus. A transition towards a more environmentally friendly economy might also require more specific competences. Both for students deciding on what education to choose and for authorities planning educational capacity, it is important to have a good understanding of future demand and supply of labour.

Studies by the European Centre for the Development of Vocational Training (2010), CEDEFOP, point out that in the future, every job will in principle be a green job. Understanding the environmental impact of an occupation needs to be mainstreamed into education and training systems. According to CEDEFOP integrating sustainable development and environmental issues into existing qualifications is much more effective than creating new training standards. Every new apprenticeship ought to have a low-carbon element, as is currently the case for instance in Australia. CEDEFOP list the following development strategies as important:

- Enabling people to increase their existing skills, through training tailored to their particular needs and made accessible through diverse range of tools and methods. However, up-skilling needs to be both affordable and profitable

- Attracting students at secondary and tertiary level into science, technology, engineering and mathematics subjects and develop these core skills which provide the basis of high level low-carbon skills

- Improving generic skills across the entire workforce. In this sense, generic skills refer to both skills required in almost any occupation and the green skills that should be part of any job

More emphasis is needed on training the trainers. There are not enough trainers and teachers aware of environmental issues and able to teach new techniques. 


\subsection{Denmark: Competence trends and mismatch}

There are fairly clear indications that despite the financial crisis, the EGSS sector in Denmark has grown markedly between 2005 and 2009 (FORA 2005, 2009; Industriens Uddannelser 2009, 2010).

Projections commissioned by the Association of Danish engineers (IDA, 2011; Damvad, 2011) indicate a lack of about 30,000 engineers and natural scientists by 2020 across all sectors if assuming the same level of growth as recently and under a low growth scenario, projections arrive at a mismatch of about 18,000 engineers and science people. Projections are based on register data and ADAM macroeconomic forecasts from Plan 2015 (Danish Ministry of Finance 2007).

Surveys and analyses of competence needs in the EGSS sector in Denmark are based on interviews with selected companies in different sub-sectors and in one case attempted scaled up to the sector as a whole. The time horizon investigated is short, about two to five years. There has to our knowledge not been any long-term analyses carried out in Denmark on the competence needs in society that mainstreams green jobs across the economy, i.e. where every job in principle will be a green job.

Surveys in selected enterprises across the EGSS sub-sectors (e.g. Industriens Uddannelser 2010, 2009; Brøndum \& Fliess 2011) show that there are no major differences between the vocational skills needed in EGSS enterprises and those required in other technical/industrial enterprises. Development of EGSS technologies are perceived to be subject to the same market-based and regulatory mechanisms and dynamics as other technological sectors and that the technological level of EGSS enterprises is not different from other production companies.

Brøndum \& Fliess (2011) compare supply and demand for newly examined engineers in order to identify potential mismatches, see Figure 4. The survey finds that over the coming two years, supply exceeds demand from the cleantech sector, except for mechanical engineering and construction. In order to meet the demand for engineers in the latter fields, it would be necessary to increase the uptake of students. 
Figure 4 Match between supply and demand of newly examined engineers in Danish cleantech enterprises

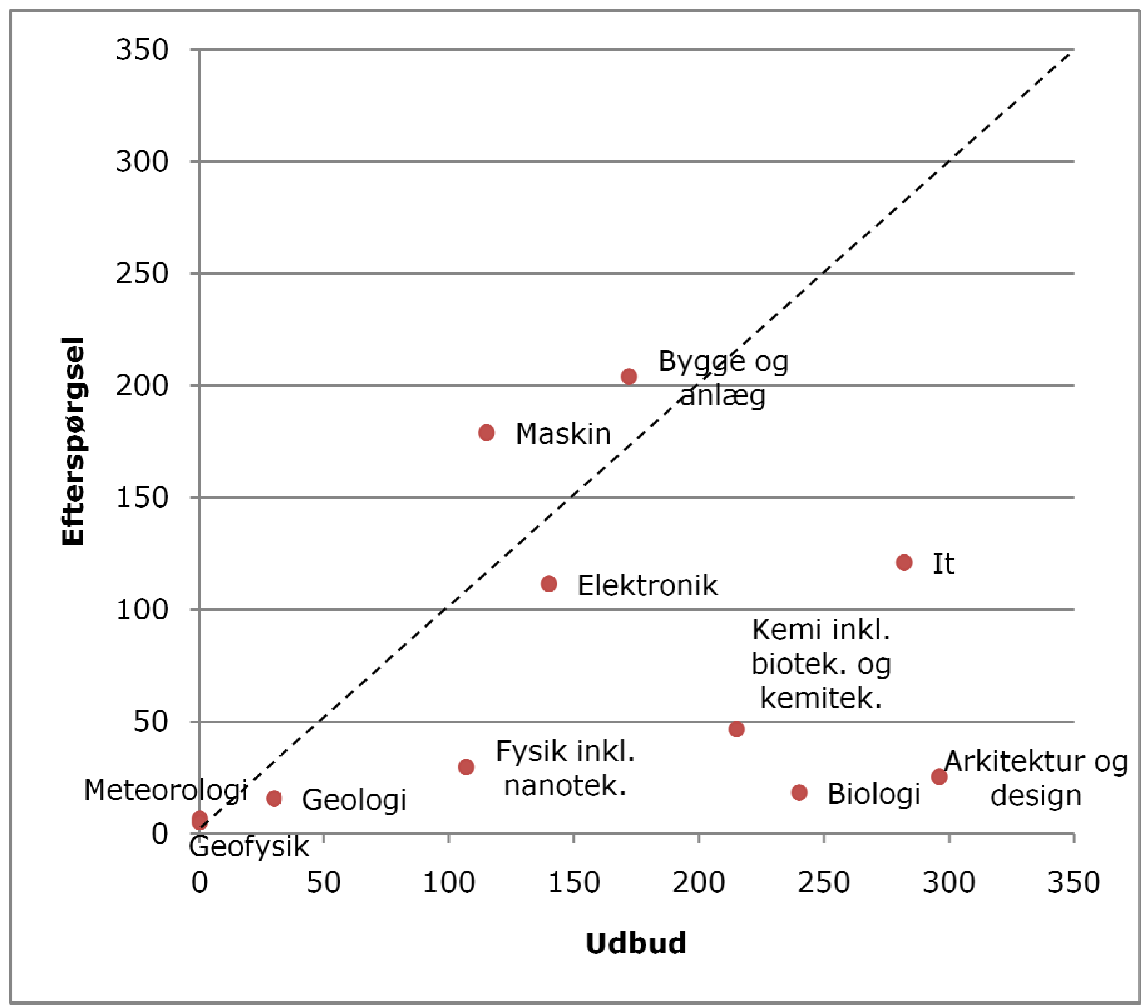

Source: Brøndum \& Fliess (2011)

The following trends with regard to the Danish EGSS sector have been identified in various studies:

- No need for new trainings \& educations: Over the next five years, there is no perceived need for developing new vocational trainings specifically targeted the EGSS sector (Industriens Uddannelser 2010, p.61)

- Research: There is a need to continue supporting existing strong research environments and to build up new ones. This requires close cooperation between public research institutions, private companies and authorities as well as knowledge exchange with international research environments (Ministry of Science Technology and Innovation, 2009)

- Increased need for skilled labour: EGSS companies report a need to employ additional skilled labour in future (Industriens Uddannelser 2010, p.32). However, the lack of training of apprentices in e.g. the wind-power industry combined with fewer young people will over 
time lead to a lack of skilled labour and bottlenecks (Industriens Uddannelser 2009)

- Risk of significant mismatch between demand and supply of engineers and natural scientists by 2020: Even conservative projections point towards a significant under-supply of engineers and natural scientists by 2020 for the economy as a whole (IDA 2011, Damvad 2011). This would inevitably mean an increased competition between the EGSS sector and other sectors for qualified staff. The projected bottlenecks, if not alleviated, would subsequently mean a reduced capacity to develop the EGSS sector in Denmark

- Increased short term need for tertiary level educated staff: A significant share of EGSS companies (ca. 1/3) demand additional civil-engineers over the near to medium future (Brøndum \& Fliess, 2011). An important share of EGSS companies demand other science trained staff and people with commercial and accounting backgrounds. Minimum requirement is a Masters degree (Industriens Uddannelser 2010). A scaled-up, conservative estimate indicates a need for close to 2000 newly graduated and qualified staff over the next two years, of which some 700 are science \& technology and engineering. Another 3600 experienced staff are expected to be employed, most of which move between companies within the EGSS sector. The development of smart-grids and smart buildings is expected to lead to high demands for it-skills (Brøndum \& Fliess, 2011)

- Increased need for international skills: There's a perceived lack of staff with international insights and language competencies as well as staff with technical skills combined with insights in other fields such as market development. There will always be a demand for innovative staff (Brøndum \& Fliess 2011). In globalised markets such as for wind energy, there's an increased need for a higher share of the staff to be willing and able to work across countries and cultures. Quality assurance and documentation is equally increasingly important in order to ensure operational reliability

- Continued need for unskilled labour: There is still a need for experienced unskilled labour in future EGSS enterprises (Industriens Uddannelser 2010, p.33). Unskilled and operational staff is perceived as very important also in future, both in order to carry out more repetition based work such as basic fitting and to keep a stable, experienced work force in-house; and

- Flexibility: The need for flexible production and innovation necessitates an integration of development and production, which in some cases leads to in-sourcing of tasks normally carried out by 
suppliers and in other cases to a reluctance to outsource parts of the production to low-income countries; and

- Dual skill development: As markets and products mature e.g. the wind energy industry, there's a need both i) for more unskilled labour capable of following precise instructions and quality measures and ii) for more integration of skilled workers in the development of prototypes, requiring certain cooperation and communication skills (Industriens Uddannelser 2009)

\subsection{Finland: Demand in 2025}

Ympäristöosaajat 2025 is a foresight project, carried out by Suomen Ympäristöopisto, SYKLI ${ }^{19}$. The project has as its goal to define what kind of know-how and skills are needed in 2025 in the environmental and energy sectors in Finland. One sector, the water sector, has so far defined specific future competences (see Vesialan osaaja 2025, 2011)20 The results of the Ympäristöosaajat 2025 project will provide input on needed competences and educational needs for all levels of education from vocational to higher education. The project will finish in 2012. Some preliminary observations about the know-how needs have already been produced in the project. These are outlined below.

According to the SYKLI project, there are growing competence needs in specific technology sectors such as the production of renewable energy, smart grid technology for electricity, technologies within energy and materials efficiency and in water technology. In addition to skills within high tech solutions there is a need for skills within so called low tech solutions, which are cost efficient and easy to implement, especially in developing countries. Technology competences are needed in research and development, as well as in practical application, for instance in finding solutions and applications for specific problems and situations. Environmental management will also need more technological skills and a general understanding of technological solutions and interdisciplinary know-how.

19 Interview and information from Kati Lundgren, Project manager for the project

20 Responsible for this project has been the Finnish Water Forum. 
According to the SYKLI project all workers and professionals need environmental skills in the future. Sustainable development and environmental issues should be mainstreamed into all existing education.

In 2025 environmental specialists need interdisciplinary know-how. They need system orientation, mastering large entities and broad expertise. Specialists should have good holistic understanding of ecological, technological, economic and social systems and interaction between and within these systems.

More skills are needed to apply environmental knowledge in practice. Environmental experts need good communications skills and also a good practical orientation to be able to participate in problem solving and to apply environmental know-how in different sectors and situations. This requires an understanding of the needs of different target groups and of local conditions.

New thinking and ability to innovate is needed. There is a great deal of knowledge of environmental issues, but the demand and supply of knowledge does not always meet. For instance, knowledge of different eco-systems is important in order to find the right expertise to solve problems. The skill to apply the knowledge to specific business activity is essential. There is also a need to have skills in guiding consumption towards for instance more energy efficient solutions and to design new solutions based on old technology and combining technologies to build new solutions. One example of such could be smart grid solutions. ${ }^{21}$

In the Ympäristöosaajat 2025 anticipation program some specific environmental sector competence profiles have been lifted to the forefront. These were described in the Vesialan osaaja 2025 report. The identified competence profiles are the super skilled, the innovators, the applicators, the "light consultants" and field workers.

The competence of the super skilled is diverse and broad based, making it possible to study problems on a systemic level. They analyse problems from an ecological, technical, economic, behavioral as well as societal perspective, while taking sustainability into consideration.

Innovators develop new solutions and can focus on societal and system level innovations and others on technological innovations, such as cleaner products or processes.

${ }^{21}$ Interview with Kati Lundgren, Project manager of the Ympäristöosaajat 2025 program 
Applicators have both environmental competence and sector as well as organization related competence and can apply environmental knowledge from both perspectives.

"Light consultants" produce services for the private consumers, small enterprises and public organizations. The services may be practical guidance, advice, consulting services and planning.

Fieldworkers may work in a very practical way in small businesses as entrepreneurs and are furnished with diverse practical skills, but expertise is also needed.

\section{Projections for competence needs in some engineering fields}

Some sectors where so called green jobs may increase were identified in Pokela et al. (2011). The study focused on three sectors, the wood based bio-economy, smart grids and sustainable communities, which were identified as being heavily influenced by the efforts to counteract climate change. These are sectors where a need for new competence is predicted. Table 21 and Table 22 present the predictions of the need of engineers and architects within these sectors. Some of these jobs may be characterised as green jobs.

Table 21 Estimate for the need for engineers (B.Sc.) within wood based bio-economy, smart grids and sustainable communities

\begin{tabular}{lrrr}
\hline & Engineers 2010 & Prediction 2030 & Prediction 2050 \\
\hline Wood based bio-economy & 13,200 & 15,000 & 17,500 \\
Smart grids & 1,000 & 4,000 & 7,500 \\
Sustainable communities & 24,500 & 26,500 & 28,500 \\
Other & 71,600 & \\
Sum & 110,300 & & \\
\hline
\end{tabular}

Source: Poleka et al. (2011)

Table 22 Estimate for the need for engineers (M.Sc) and architects within the woodbased bioeconomy, smart grids and sustainable communities

\begin{tabular}{lrrr}
\hline & M, Sc. and architects 2010 & Prediction 2030 & Prediction 2050 \\
\hline Wood based bio-economy & 5,300 & 6,000 & 7,500 \\
Smart grids & 500 & 2,500 & 5,000 \\
Sustainable communities & 12,700 & 14,000 & 15,000 \\
Other & 44,700 & \\
Sum & 63,200 & \\
\hline
\end{tabular}

Source: Poleka et al. (2011) 


\subsection{Norway: Demand and supply by education}

Grünfeld and Espelien (2011) discuss the competence profile and needs for companies in 11 identified environmental sectors in Norway, focusing on renewable energy and environmental technologies. The discussion is based on the so called EKN survey, a survey targeted towards companies with activities in clean energy and environmental technologies. In total 226 companies answered the questionnaire.

Some of the main findings from the EKN study are a high competence level and a somehow untraditional recruitment processes. Many of the technology areas in renewable energy and environmental technologies are relatively new disciplines, and in some cases there are no programs at colleges and universities covering the fields. Employees are therefore to a certain degree recruited from abroad, they are offered supplementary training or trained through regular work.

When comparing the results from the EKN survey with figures from Statics Norway on educational level for the whole business sector it becomes evident that the environmental sectors are more competence

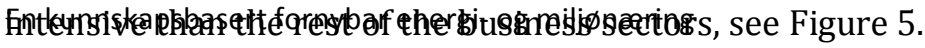

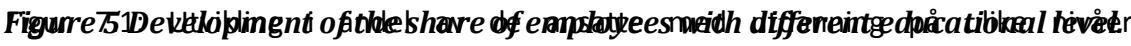

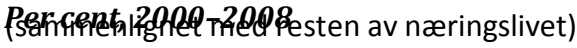

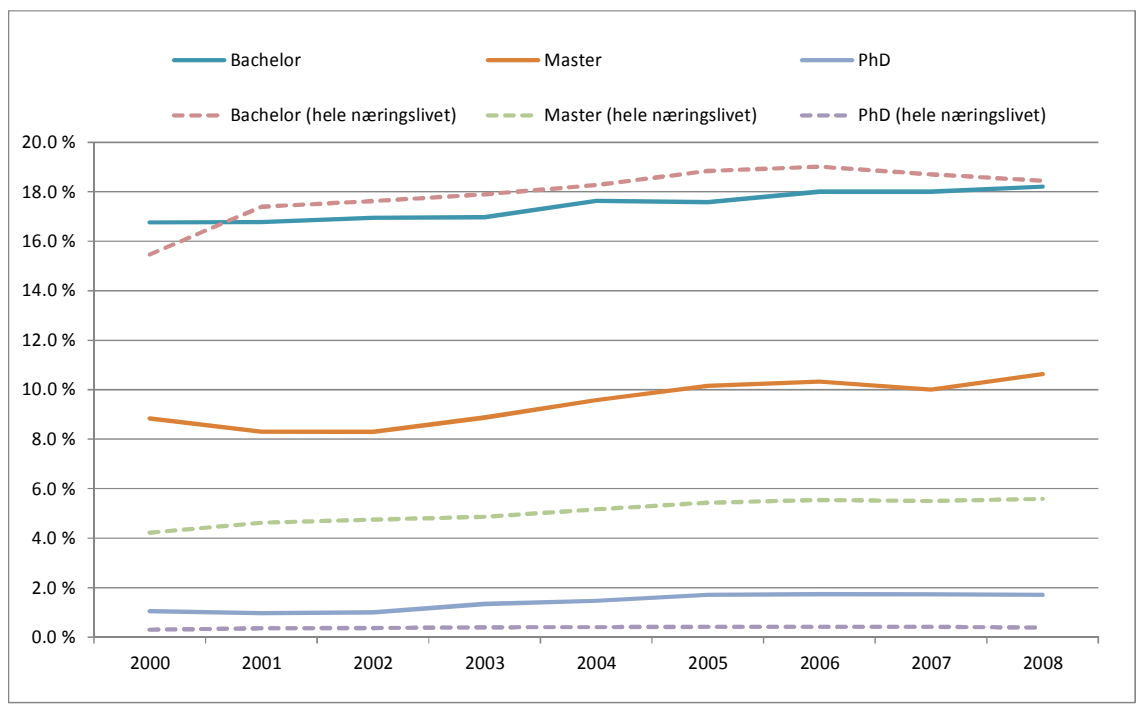

Source: Grünfeld and Espelien (2011)

Figuren viser at utviklingen i næringen gjennomgående trekker i retning av økende utdanningsnivå gjennom det siste tiåret. Næringen fremstår som særlig kunnskapsintensiv sammenlignet med resten av næringslivet, og her er det noen trekk som det er spesiell grunn til å feste seg ved. Adelen med bachelorutdanning er på linje med det vi finner i resten av фkonomien, men andelen med de høyeste utdanningsbakgrunnene er betydelig st $\varnothing r r e$. På masternivå ligger andelen dobbelt så høyt og andelen med PhD ligger fire til fem ganger så høyt. For den siste gruppen har også veksten vært betraktelig høyere. Dette illustrerer på en god måte hvor sterk satsningen har vært på utdanning fra offentlig sektors side, og samtidig at næringen har klart å absorbere den økte tilstrømmingen av kandidater med høy utdanning og vitenskapelig bakgrunn. Samtidig tydeliggjør mønsteret at denne næringen på mange måter er mer teknologintensiv enn andre næringer og at den på mange områder og innen mange segmenter er på et tidlig utviklingsstadium. 
Decomposing these figures in four different environmental sub sectors shows that there are large differences when it comes to educational level in these sectors, see Figure 6. The lowest educational level is in waste treatment, as would be expected since this is a sector with a rather high labour intensity and a high portion of unskilled labour. It is in the rather broad sector environmental technology that the competence level is especially high.

Figure 6 Educational level in four environmental sectors

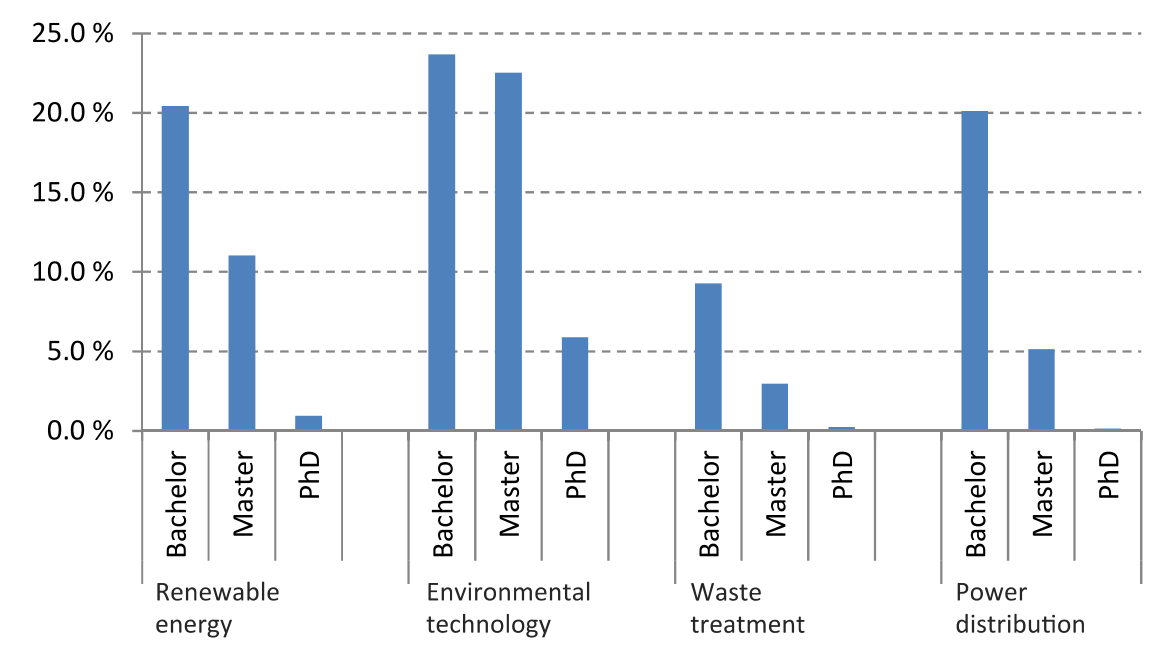

Source: Grünfeld and Espelien (2011)

Grünfeld and Espelien (2011) also presents figures of the composition of different educational fields in the environmental sectors, see Figure 7. The environmental sectors have a much higher share of engineers than the rest of the business sector, and also nearly the double of employees with natural science education compared with the rest. From 2000 to 2008 there has been a rather large decrease in share of employees with a higher degree in the environmental sectors, and especially for engineers. According to Grünfeld and Espelien (2011) this might be a signal that the sectors are struggling to attract the needed competence. 
Figure 7 Educational fields for employees with a higher degree in environmental sectors compared to the whole business sector

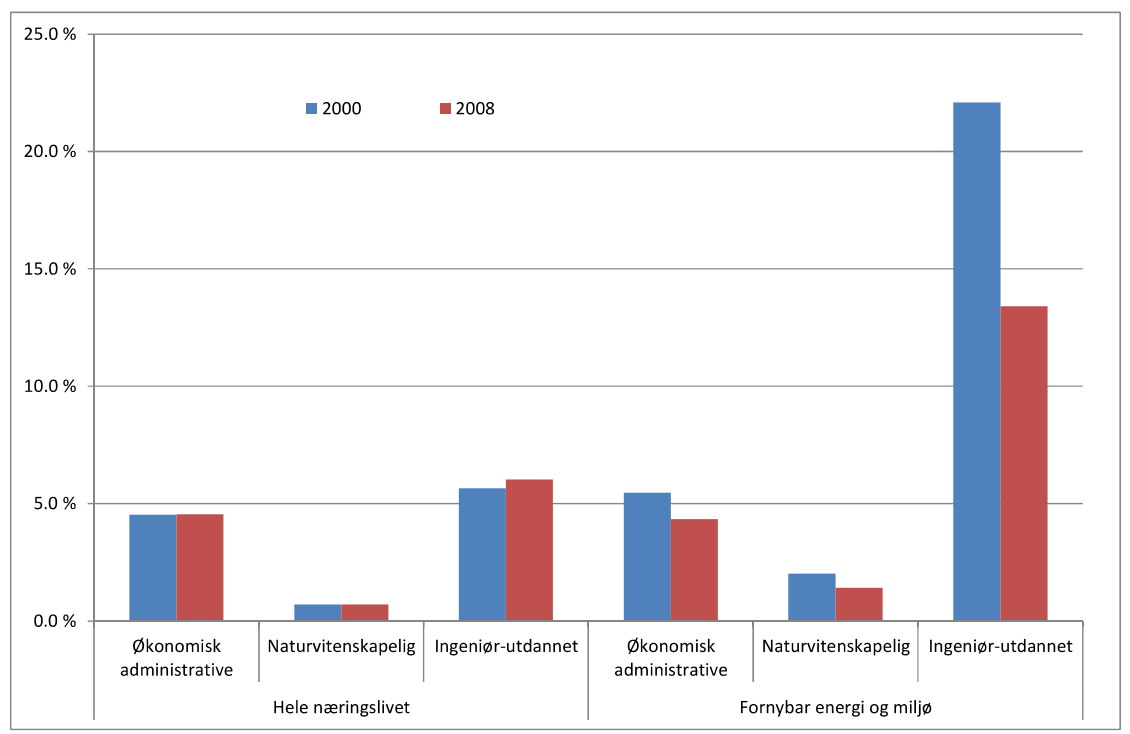

Source: Grünfeld and Espelien (2011)

Statistics Norway more or less regularly presents projections of the demand and supply of labour by educations, the latest covering up to 2030, see Bjørnstad et al. (2010).

The projections show that the present trend with increased demand for workers with a tertiary education and upper secondary vocational education will continue. In 2030 only 18 per cent of the employed will have primary or lower secondary education, compared to 27 per cent in 2007 and 27 per cent (estimated) in 1972. The demand for labour by educational fields is presented in Figure 8-10, showing upper secondary school level, lower tertiary degree and higher tertiary degree. 
Figure 8 Employment by education at upper secondary school level. 1,000 persons

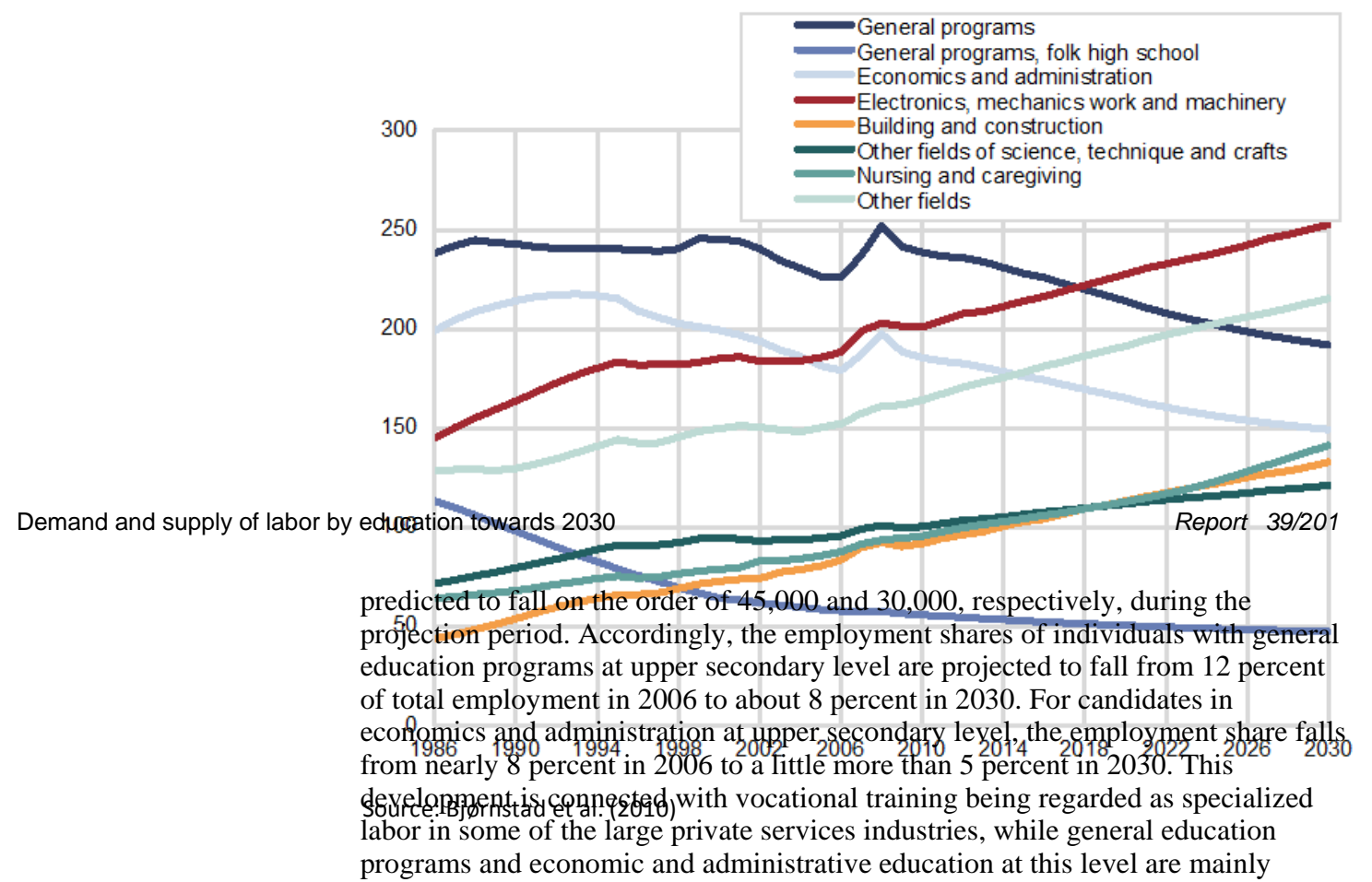

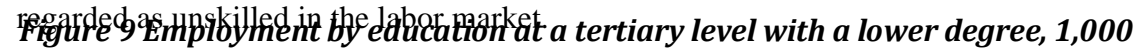

pigrsan.3.Employment by education at a tertiary level with a lower degree, 1,000 persons

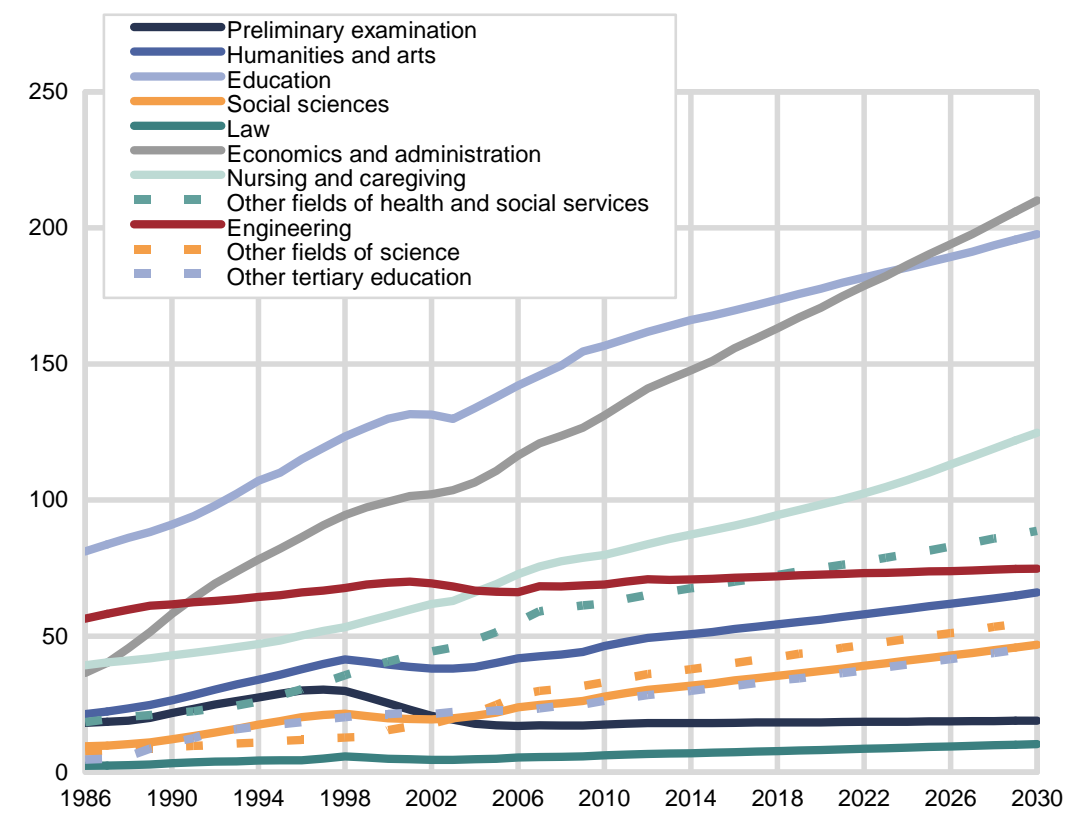

Source: Bjørnstad et al. (2010)

Figure 7.3 shows the development in demand for labor among the fields at a lower tertiary level. The figure indicates employment growth within all fields, particularly for candidates specializing in economics and administration. By 2030, the employment of individuals with this qualification is expected to expand by almost 100,000 persons, making this occupational group the largest at the lower tertiary level. More than one in five individuals holding a lower degree at the tertiary level is specialized in economics and administration in this year. The demand for this type of skilled labor may especially grow in the service industry, but the banking and insurance industry, public sector and the manufacturing

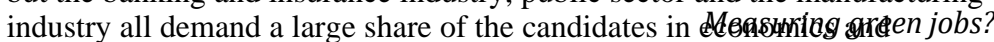
administration. 
predicted to fall on the order of 45,000 and 30,000, respectively, during the projection period. Accordingly, the employment shares of individuals with general education programs at upper secondary level are projected to fall from 12 percent of total employment in 2006 to about 8 percent in 2030. For candidates in economics and administration at upper secondary level, the employment share falls from nearly 8 percent in 2006 to a little more than 5 percent in 2030. This development is connected with vocational training being regarded as specialized labor in some of the large private services industries, while general education programs and economic and administrative education at this level are mainly

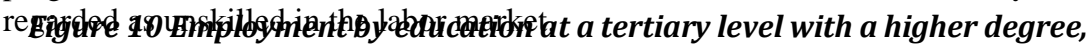

1,000 persons

Figure 7.3.Employment by education at a tertiary level with a lower degree, 1,000 persons

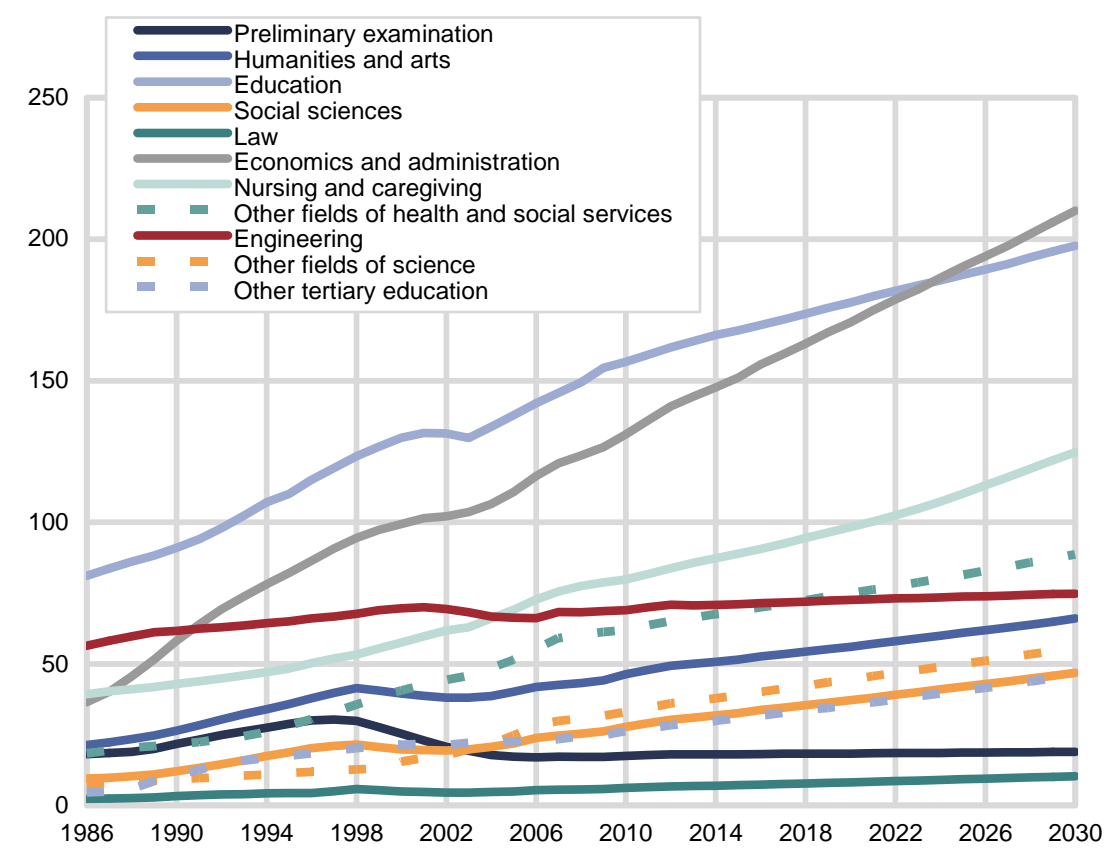

Source: Bjørnstad et al. (2010)

Figure 7.3 shows the development in demand for labor among the fields at a lower

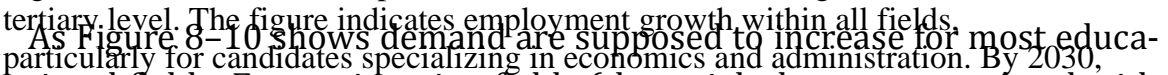

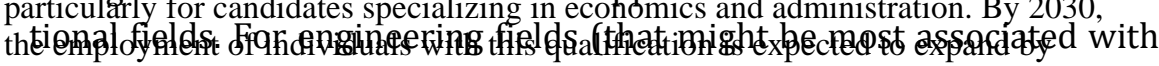

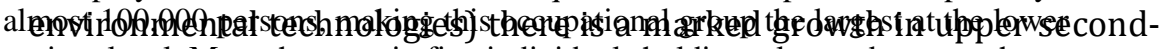
tertiary lovel Morecthan on in five individuals holding a lower degree at the tertiary

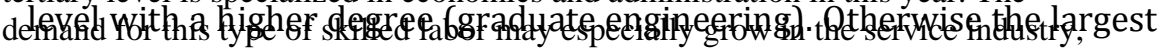

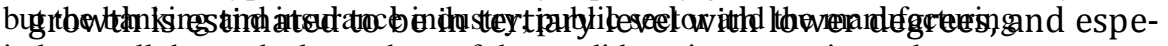

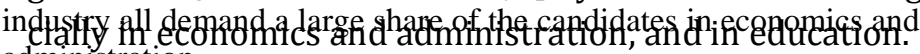

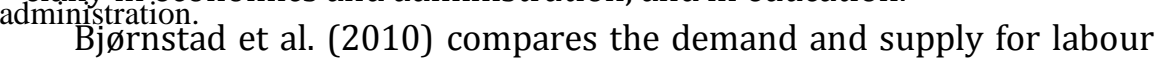

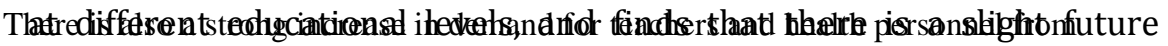

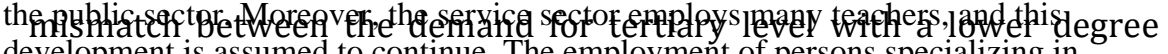

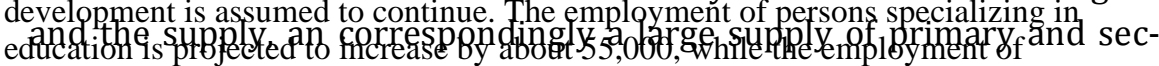

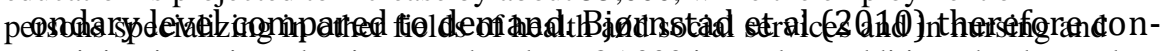

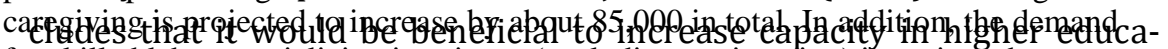
for skilled labor specializing in science (excluding engineering) is projected to expand bypecialy 30,000 people, increasing its share of total employment of candidates with a lower tertiary education from 5 percent in 2006 to 6 percent in 2030. This demand increase mostly stems from the service industry. Employment of candidates with specialization in humanities and the arts is also predicted to 


\subsection{Views from some central actors}

In addition to the official reports presented above we have also been in contact with some central actors in order to understand how they assess present and future challenges matching the demand for environmentally skilled labour with the supply.

\subsubsection{The Nordic Federation of enterprises}

Representing future employers the national federations of enterprises have an interest in educational and competence issues. We have interviewed representatives from the federation of enterprises in Norway, Iceland and Sweden. In addition, we have used written statements and reports from their sister organisations in Finland.

Norwegian Federation of Enterprises points at the general need for science/mathematics and engineering competence, referring to clear feedback from their members on these issues. In addition to higher degree education in the mentioned fields, there is a need to strengthen vocational training and target it towards the needs of the industry. The use of apprentices and learning through work experience are seen as important.

Norway has a special challenge, or opportunity, having a large petroleum sector. This sector demands a large part of the competence base making it difficult for other sectors to compete for the best competence. But this sector is also the foundation for a large supplier industry that can be vital in greening the economy. Suppliers to the petroleum sector can also deliver services to more "green" industries, as far as it is possible to divide between green and non-green industries. Having a large energy sector, with special competence in hydropower can offer "green" business opportunities, providing the existence of the right engineering and marketing competence. It is also important to develop IT skills, as these often are important in the transition towards a more environmental friendly business sector, including better energy management systems, more efficient processes and replacing physical communication.

Swedish Federation of Enterprises stresses that the engineering education needs to adapt towards environmental issues and needs, and that this should not be limited to programs and fields that are more or less "pure" environmental engineering but also be important for all other fields of technical science as well. According to the Swedish Federation the present education system is not functioning well enough in this respect. The high unemployment among young people in most Nordic countries can partly be explained by the mismatch between the education system and the 
needs from the business sector. A recent mapping of the employment five years after ended vocational education shows that students at construction, electro and energy, and vehicle and transport programs have the highest probability to get a work within 5 years, whereas child and recreation programs have the highest unemployment rate. ${ }^{22}$

According to the Icelandic Federation of Industries specific skills, which are needed for the development of green business, are very much the same as are needed for other business as well. It is necessary to improve marketing skills in the cleantech sector, as this sector need to focus on export opportunities. The major challenges in the development of the cleantech sector are more in financing small businesses and startups, and not so much in specific technical skills. At the moment there is insufficient access to capital (loans, seed money), which hampers development more than the lack of specific skills. ${ }^{23}$

According to the Confederation of Finnish Industries (2011) it is important to be able to develop eco-efficient solutions and to grow new green business. In order to do this strong business skills as well as innovativeness and entrepreneurship are needed. Without this it will not be possible to realize the possibilities the growing international markets present. Especially small and medium sized companies need help with marketing, commercialization as well as with internationalization. In addition to creating new businesses, there is also the need to develop existing businesses so that it can answer to the challenges posed by the green economy. There is a need to be able to identify new growth areas and to be able to listen to signals from the outside world. Strategic level competences, thus, rise to the forefront. ${ }^{24}$

\subsubsection{Other actors}

The importance of increased competence about environmental technology, includes, according to the Norwegian Research Council (NFR) several different perspectives:

\footnotetext{
22 See http://www.svensktnaringsliv.se/fragor/kvalitet-i-grund-och-gymnasiet/manga-utbildningar-ledertill-arbetsloshet_148969.html.

23 Interview of Bryndis Skúladóttir, Icelandiic Federation of Industries

24 Yritykset vihreän talouden eturintamassa, Confederation of Finnish Industries, 2011
} 
- Environmental technology and green business are broad concepts, making it difficult to pinpoint future needs for certain technologies and expertise

- All types of education need to increase the elements of green thinking. Both as consumers and producers we should be able to demand environmentally friendly (or less harmful) products. This perspective makes it necessary to integrate environmental issues in all parts of the education system

- Support from actors like the Research Council's is important for the development. Scientists participating in "green" research are likely to use the knowledge acquired in this research in teaching activities. This is an important connection between research and education/teaching

NFR claims a need to strengthen the emphasis on green perspective in all education. Environmental issues should not be separated out as special educational programmes, but rather be central in all education. One illustrative example is the building and construction education where tertiary education to a large extent focuses on environmental and energy issues, whereas the secondary vocational education to a larger degree focuses on the construction process, and where one probably lack a comprehensive environmental perspective. In addition the competence of end-users needs to be strengthened, in order to be able to demand the necessary environmental standards in products and services.

Vinnova, the Swedish Governmental Agency for Innovation Systems, also stresses the importance of environmental technologies, and that the demand for these technologies is likely to increase. But they also points to the fact that environmental knowledge is becoming increasingly important in areas and fields where it previously has not been necessary, like in pharmaceuticals, health, financial, and law. Generally, todays engineering education has a strong focus on problem solving, but it might lack more basic environmental knowledge, i.e. the natural science perspective. Such competence is necessary to be able to respond to the challenges the society face.

Environmental knowledge is also important in primary schools, but at least in Sweden this perspective is already well covered. In higher education, fields that traditionally have been associated with the use of natural resources have the necessary environmental knowledge, whereas it might be lacking in other programs. According to Vinnova a general challenge for Sweden is the integration between higher education and research. Research is often too academic and not tuned to innovation and business needs. 
According to the Icelandic Ministry of Education, Science and Culture the education system is geared to the environmental industry and workplaces. It is generally considered as very important for the economy. There has not in reality been a large paradigm shift in government, but a more conscious decision has now been made to pursue green growth. Iceland has long been considered a green place to live by Icelanders. This is partly so because there is limited use of fossil fuels except in the transport sector. ${ }^{25}$

A new national curriculum is currently under development in Iceland. It is based on 6 pillars of which sustainability is one of the pillars. The goal for the future is that sustainability will underpin any development and job. The new curriculum includes a description of the key competences for further education. It includes a description of required key competences including those required in the environmental sectors. This curriculum and list of competences is not yet available ${ }^{26}$.

Generally, it can be said that the education system in Iceland faces some challenges, the least not being that there is a need to attract students to technical subjects, which are not at the moment seen as very attractive. There is also a need to do some systemic changes to the education system to be able to ensure that a greater part of the Icelanders finish secondary education. ${ }^{27}$

\subsection{Summing up}

A general finding in our mapping is that the present education system needs to become more responsive to the needs of the surrounding world. The distance between education and the actual needs in industry and business sectors must be shortened. In many cases there is a poor matching between present education and work opportunities. This holds for both vocational training and higher education. A rapid trend in the Nordic countries, as well at the whole of Europe, is that jobs are getting more qualified, and the proportion of jobs requiring low skills becomes smaller. This is a trend that has nothing to do with green or environmentally friendly technologies, but such technologies can provide both low and high skilled jobs. The main educational fields demanded in the

\footnotetext{
25 Interview of Rósa Pórðardóttir, Special adviser at the Ministry of Education, Science and Culture ${ }^{26}$ This list is currently under translation.

27 Interview of Rósa Pórðardóttir, Special adviser at the Ministry of Education, Science and Culture
} 
"green" sectors are technical and engineering, but also different forms for marketing skills.

There is however a need to mainstream environmental education and develop green skills within all educational sectors. The need for additional workforce with very specialized green skills will be low in the future. Improving green skills in existing jobs will be very important. This is illustrated in Figure 11.

Figure 11 CEDEFOP classification of skills needed for a transition to a low carbon economy

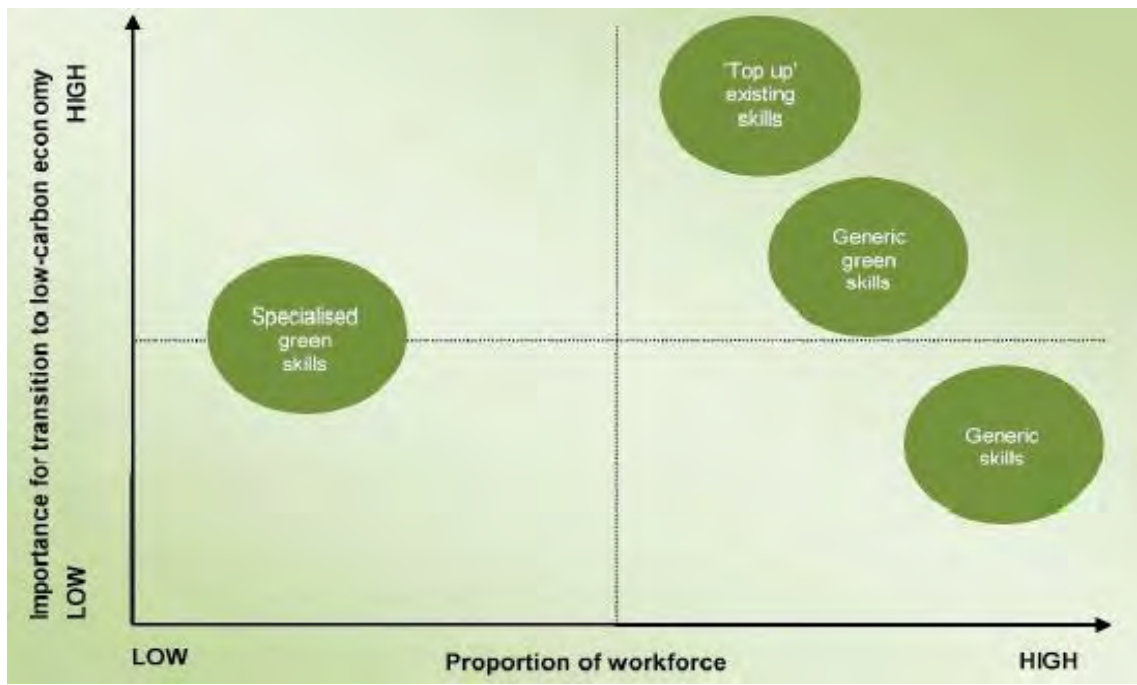

Source: CEDEFOP 



\section{Alternative proposal}

As we have argued in Chapter 3 and 4, it is not possible to make consistent divisions between "green jobs", "green sectors" and "clean economy" and, implicitly, "non-green jobs", "non-green sectors" and "dirty economy". The initiatives to measure green activities seem to be motivated by a need of insight into the level and potentials of environmental pressure, environmental responses, and the economic and employment responses. A categorization of "green" and "non-green" activities is unfit for such analyses, as the delineation is subjective, and the conclusions are predetermined during the categorization process.

Instead, we suggest the use of data from emission inventories and national accounts as bases for the requested information, and, if necessary, to further disaggregate these if the detailing level is not sufficient disaggregated. Data on environmental damages on detailed sector level exist for most countries. Due to the transparent and objective nature of emission statistics, the information is easily interpretable. The higher detailing level, the more relevant is the information concerning different technologies producing comparable (homogenous) goods and services.

This approach offers insights into the environmental load per produced unit, and per employed worker, without subdividing the economy into two categories as in EGSS framework. Instead, this measures the relative greenness, possibly ranging the activities along a continuous scale.

This framework requires detailed data on:

- Environmental impact (for instance emissions to air, water, land, noise, biodiversity etc)

- Production

- Employment

Comparison can be made between different types of industries, and if sufficiently detailed, data can range the environmental load in different e.g. agricultural technologies (ecological versus conventional) for homogenous products (such as meat and milk). 
If more than one environmental aspect is requested, the different environmental problems can be aggregated. However, this aggregation brings in another subjective element that disturbs the objectivity in the information. The aggregation requires weights, and since such weights are not given in the market, estimates on marginal environmental damages must be used. The choice of estimation methods are generally based on a range of normative evaluations, and the estimates also imply subjective choices. A large literature offer estimates which can be used in such aggregation (Champ et al. 2003, Hanley and Barbier 2009, Bateman and Willis 1999, the EU ExternE). However, if such aggregation is performed, it is important to report transparent information on what estimates are used and the uncertainty relative to other studies.

The environmental load should be limited to the direct effects of the production and consumption processes. Indirect effects through the life cycle should be ascribed to the activity where the emission takes place, in line with the statistical bureaus official emission inventories. If these statistics are harmonized with the national accounts (cf NAMEA) - it is possible make input/output analyses in order to follow the total impact from each activity.

Advantages with such a framework comprise that:

- it is possible to identify the most polluting sectors

- environmental load per sector can be identified, without using normative borders for which activities are "good" and "bad"

- the number of employees in different sectors with different environmental loads can be measured and compared

- input/output analyses to analyse total impact of different policies addressing environmental problems can be done

- the framework can be based on existing national and international emission inventories. For harmonized sector levels principle, international comparisons are possible

Part of the motivation for the "green" statistics is to casts light on future potentials for greening of the economy. Forecasts studies offer information on possible environmental development paths and may reveal need for action. The need for increased competence relative to present can be identified, which can form a basis for recommendations of planning of the education sector 


\subsection{Need for numbers}

To make comparable statistics, the data requirement is data on environmental load (emissions to air, water, land, noise, biodiversity, etc), production data and employment data on detailed sector levels. Calculations of relative greenness across environmental problems require additional marginal damage estimates.

\subsubsection{Production, employment and emission data}

\section{SEEA and NAMEA}

The Eurostat System of Environmental - Economic Accounting (SEEA) Central Framework is a conceptual framework that describes the interactions between the economy and the environment (The Committee of Experts on Environmental Economic Accounting 2012). The framework provides a structure to compare and contrast source data and allows the development of aggregates, indicators and trends across a broad spectrum of environmental and economic issues. Particular examples include the assessment of trends in the use and availability of natural resources, the extent of emissions and discharges to the environment resulting from economic activity, and the amount of economic activity undertaken for environmental purposes.

The framework covers the stocks and flows that are relevant to the analysis of environmental and economic issues. The framework brings together, in a single measurement system, information on water, minerals, energy, timber, fish, soil, land and ecosystems, pollution and waste, production, consumption and accumulation. The concepts and definitions that comprise the SEEA Central Framework are designed to be applicable across all countries, regardless of their level of economic and statistical development, their economic structure, or the composition of their environment.

The data follows the statistical classification of economic activities in the European Community (NACE). Examining environmental variables together with economic ones helps identify which economic activity contributes to which environmental pressure and is thus helpful in devising specific policy measures where most needed. 
The NAMEA (national accounting matrix including environmental accounts) is a system to combine national accounts and environmental accounts in a single matrix, and serves an example of a database including the relevant data. Table 23 illustrates an example of the use of Norwegian NAMEA-statistics in the relative greenness framework. Based on data for production, employment and emissions, relative emission intensities are calculated for different activities to illustrate relative "green production". Further, if requested, such relative comparisons can be calculated for environmental load per employed worker, to illustrate the relative "green employment".

This NAMEA system is part of the SEEA and has been applied in several European countries (CPS 2008) (such as Denmark, Norway, Sweden, Germany, the Netherlands, the UK) ${ }^{28}$. Data exist on 7-digits NACE level and opens for detailed analyses on a disaggregated level.

If the statistics limits the needs for detailed statistics, further data work may be necessary. For example, damages to nature, loss of biological diversity etc. should also be included in order to cover the whole range of environmental problems, and to make proper analysis on environmental load from different production technologies related to homogenous products. Another example is that it is not possible to study the emissions per produced unit and per employee in ecological versus conventional production of agricultural products. The need for new statistics should always be based on thorough evaluation of the purpose it may serve.

${ }^{28} \mathrm{http} / / /$ www.isa.org.usyd.edu.au/research/nea.shtml 
Table 23 An example of the relative greenness framework based on production (2005-prices), employment, and emissions statistics in 2010, Norway

\begin{tabular}{|c|c|c|c|c|c|c|c|c|}
\hline & \multirow[b]{2}{*}{$\begin{array}{r}\text { Production } \\
\text { (mill NOK) }\end{array}$} & \multirow[b]{2}{*}{$\begin{array}{r}\text { Employ- } \\
\text { ment } \\
(1000)\end{array}$} & \multicolumn{2}{|c|}{ Emissions } & \multicolumn{2}{|c|}{$\begin{array}{l}\text { Emission intensity } \\
\text { (emissions/ NOK) }\end{array}$} & \multicolumn{2}{|c|}{$\begin{array}{l}\text { Emissions em- } \\
\text { ployment intensi- } \\
\text { ty (emissions } \\
\text { /number of } \\
\text { employed) }\end{array}$} \\
\hline & & & $\begin{array}{c}\text { co2-eq, } \\
\text { tonne }\end{array}$ & $\begin{array}{r}\text { Acid } \\
\text { (NOX, } \\
\text { SO2, } \\
\text { NH3) }\end{array}$ & $\begin{array}{c}\text { Green- } \\
\text { house } \\
\text { gases }\end{array}$ & Acids & $\begin{array}{c}\text { Green- } \\
\text { house } \\
\text { gases }\end{array}$ & Acids \\
\hline $\begin{array}{l}\text { Agriculture, } \\
\text { forestry, fishing }\end{array}$ & 69,206 & 61 & 6,321 & 1763 & 91.3 & 0,0255 & 103,6 & 28.9 \\
\hline $\begin{array}{l}\text { Mining and } \\
\text { quarrying }\end{array}$ & 486,904 & 54 & 14,253 & 1227 & 29.3 & 0,0025 & 264,0 & 22.7 \\
\hline Industry & 610,332 & 207 & 12,552 & 944 & 20.6 & 0,0015 & 60.6 & 4.6 \\
\hline $\begin{array}{l}\text { Energy and water } \\
\text { supply, drainage } \\
\text { and renovation }\end{array}$ & 80,154 & 27 & 3682 & 119 & 45.9 & 0,0015 & 136,4 & 4.4 \\
\hline Transport & 267,337 & 457 & 20,464 & 5571 & 76.53 & 0,0208 & 44.8 & 12.2 \\
\hline $\begin{array}{l}\text { Building and } \\
\text { construction }\end{array}$ & 254,862 & 26 & 841 & 101 & 3.3 & 0,0004 & 32.4 & 3.9 \\
\hline $\begin{array}{l}\text { Retail, reparation } \\
\text { of motor vehicles, } \\
\text { accommodation } \\
\text { and serving }\end{array}$ & 386,143 & 182 & 680 & 33 & 1.8 & 0,0001 & 3.7 & 0.2 \\
\hline Services & 846,963 & 361 & 806 & 36 & 1.0 & 0,00004 & 2.2 & 0.1 \\
\hline $\begin{array}{l}\text { Education, health } \\
\text { and social services }\end{array}$ & 331,201 & 601 & 446 & 16 & 1.3 & 0,00004 & 0.7 & 0.0 \\
\hline $\begin{array}{l}\text { Public administra- } \\
\text { tion and defence }\end{array}$ & 170,672 & 168 & 300 & 49 & 1.8 & 0,0003 & 1.8 & 0.3 \\
\hline
\end{tabular}

Source: http://www.ssb.no/emner/09/01/nrmiljo/tab-2012-02-13-01.html

\section{OECD and UN databases}

The OECD ${ }^{29}$ and $\mathrm{UN}^{30}$ databases seem to be less coordinated and not detailed enough to conduct comparisons between countries on a detailed sector level. The sector specification of production, employment and emissions do not match within or between the databases. The OECD offers data on production by country and by sectors ${ }^{31}$ (industry, manu-

\footnotetext{
29 http://stats.oecd.org/Index.aspx

$30 \mathrm{http}: / /$ unstats.un.org/unsd/default.htm

31 http://stats.oecd.org/index.aspx?queryid=90
} 
facturing, manufactured intermediate goods, manufactured investment goods, energy and construction). Employment is given by main activities that do not generally match with the sector specification. ${ }^{32}$ The production and employment sectors do not match entirely, but some sectors are comparable. The UN database has data on emissions by sector and by country33, but the sector specification differs from the Eurostat or OECD specification. The sector level for emissions and employment and production do not match. This calls for a harmonisation applying detailed and aggregate ISIC codes as a standard.

\subsubsection{Marginal cost estimates}

To estimate the total environmental pressure per sector activity, the emissions and other damages have to be weighed together. For example, in Table 23, marginal damage estimates for $\mathrm{CO}_{2}$ and acids could be used to estimate each sectors' environmental load. Note that the information then departs from descriptive to normative, as we face the difficult normative choices of choosing weights, formulated as environmental goods valued in monetary terms. Hence, it is crucial to be open on what estimates and values are used, and the uncertainty in the estimates. Over the past 20 years, there has been much progress in the analysis of environmental damage costs, see Hanley and Barbier (2009), Champ et al. (2003) and Bateman and Willis (1999). A particularly relevant project is the EU ExternE (External costs of Energy) European Research Network. Since 1991, the project has involved more than 50 research teams in over 20 countries.

$32 \mathrm{http://stats.oecd.org/Index.aspx}$

${ }^{33}$ http://unstats.un.org/unsd/environment/air_greenhouse_emissions $\% 20$ by $\% 20$ sector.htm 


\section{Summary and conclusions}

This report looks into the attempts to single out the green activities, such as green sectors, green businesses and green jobs. We conclude that it is theoretically and empirically impossible to make consistent frameworks for such a division of the economy into green and non-green activities.

All activities bring along some level of environmental pressure, and are hence more or less green. Since all activities are more or less emission and resource intensive, singling out green activities will depend on where in this continuum and according to which criteria one decides to put a dividing line. There is no theoretical foundation for where to put such a dividing line and practises between countries and institutions differ. The statistics cover different functions with respect to whether they contribute to avoiding or treating environmental damages. As a summary of the practical approximation in the initiatives, green sectors comprise those dealing with prevention, and mitigation of pollution, and sectors with relatively lower polluting technologies than other alternatives.

Due to the normative judgments, the figures available are difficult to compare and interpret. A large share of green sectors do not necessarily mean ambitious, effective or successful environmental policies, but could be an expression of a very bad environmental situation to deal with, a large backlog of problems compared to other countries or oldfashioned and inefficient policy strategies. Renewable energy is typically defined as green, while fossil fuels are considered non-green. However, production of renewable energy such as hydro, wind power and biofuels also implies environmental costs; degradation of pristine nature, aesthetical disturbance, costs to biological diversity and use of energy input in the production. On the other hand, natural gas is far less carbon intensive than coal, and maybe also compared to biofuels and hydro, if considering carbon released from land clearance.

Good and inspiring examples of successful companies and increasing employment in recycling, environmental protection and renewable energy will be important for the discussion of the effects of environmental policies. But it would be misleading to put too much effort into overprecise calculations, statistics and accounts for a distinct category of green sectors and jobs, which are not separate in any clear and absolute way from other economic sectors. 
The economically optimal way to reach environmental targets is to use general instruments securing equal marginal abatement costs across sectors. Such instruments comprise environmental taxes and cap, trade systems and general regulations securing cost efficient emission reductions and nature preservation. The determination of environmental targets, and hence weighing of environment and production of diverse goods and services, is a normative issue to be made by the elected politicians. The resulting combination of production, emissions and employment must balance to provide the desired bundles of goods and service. The activities are generally mutually dependent and interactive. While some sectors face significantly higher emissions per produced units and per employed workers than others, the interaction with other activities makes it impossible to ascribe environmental responsibility to some predefined activities. Hence, pollution and resource use are some out of many costs that must be accepted in an economic system to benefit from other goods and services production. In an economic perspective, it is hence not meaningful to prescribe some form of responsibility for environmental damages to certain activities.

The importance of greening the overall, aggregate, economy, including all sectors, has been stressed in most work on green growth recently, e.g. in the OECDs Green Growth Strategy (OECD 2011). This is a further warning against an emphasis on measuring green activities, such as the number of green jobs and green companies.

To investigate the environmental load per sector and per employee, we propose to use conventional data on emissions and resource use on detailed sector levels. Such statistics offer transparent, objective and interpretable information. The higher detailing level, the more information is available when comes to different technologies producing comparable (homogenous) goods and services.

The demand for green activity data is driven by the need for international comparisons, and to track progress on environmental progress in different companies, sectors, companies and the economy as a whole. Environmental authorities and politicians ask for information to demonstrate the effects of environmental policies. Countries with high unemployment seek new business opportunities and additional jobs for economic growth. The use of conventional statistics covers all these information needs. Environmental load per sector can be identified, without using normative borders for which activities are good and bad. The emission inventories identify the sources for emissions and offer the highest quality sources of information for development of efficient abatement policies. 
The number of employed in different sectors with different environmental loads can be measured and compared when this information is requested. Economic forecasts show possible environmental development and need for action and competence can be identified relative to present. Conventional statistics is also the main source for ex post and ex ante analyses of the effects of environmental policy. Calculating and accounting for the macro-economic, environmental and employment effects of alternative economic and environmental policies is in any case best done through macro-economic modelling. Such models are necessary to capture the net effects of changes in the national economy as a whole.

The framework can be based on existing national and international emission inventories. The present aggregation levels, such as in the European SEEA framework, do not necessarily meet the needs for detailed analysis as requested by the politicians and other users. The future strategy will be to identify of what detailing level is requested in what sectors, and why. It may then be necessary to make further specifications to produce the desired statistics. This can imply further disaggregation or side models within the existing (e.g. SEEA) framework. To include the range of environmental problems, damages of nature, loss of biological diversity etc. should also be included. Finally, if a more general picture of the total environmental pressure per sector is requested, emissions and other damages can be weighed together using cost estimates from the literature.

The report further looks present and future economic structures and needs for labour to meet environmental challenges. A clear trend in the Nordic countries is that jobs are getting more knowledge intensive. This trend has nothing to do with green or environmentally friendly technologies, but such technologies can provide both low and high skilled jobs. The main educational fields in demand by sectors usually referred to as green (such as renewable energy) are technical and engineering, but also different forms for marketing skills. In general, a high competence level contributes to a more efficient economy in inputs, including factors benefiting the environment. More efficient production processes imply reduced use of material and energy inputs and hence lower environmental pressure. Higher competence levels may increase the general knowledge level, including environmental consequences. Environmental policies will influence relative competitiveness of different sectors and hence the demand for educated labour. From a policy point of view it is difficult to point out specifically which types of education will be most important to support in the future in an environmental perspective. 



\section{References}

Bateman I. and K. G. Willis (1999): Valuing Environmental Preferences: Theory and practice of the contingent valuation method in the US, EU, and developing countries. Oxford University Press.

Bjørnstad, R., M. L. Gjelsvik, A. Godøy, I. Holm and N.M. Stølen (2010): Demand and supply of labor by education towards 2030. Report 39/2010, Statistics Norway, Oslo.

Brolinson, H., M. Cederlund and M. Eberhardson (2006): Environmental goods and services sector in Sweden 2002-2005. Statistiska centralbyrån (Statistics Sweden) \& Eurostat.

Brøndum \& Fliess (2011): Undersøgelse af uddannelses- og kompetencebehov blandt cleantech-virksomheder. Fokus på match mellem efterspørgsel og udbud af uddannelser og kompetencer. Klima- og Energiministeriet og Ministeriet for Videnskab, Teknologi og Udvikling.

Bureau of Labor Statistics: The BLS Green Job Definition. http://bls.gov/green/ green_definition.pdf

Champ P. A., K. Boyle and T. C. Brown (2003): A Primer on Non-market Valuation. Kluwer Academic Publishers, Dordrecht.

Confederation of Finnish Industries (2011): Yritykset vihreän talouden eturintamassa.

Confederation of Finnish Industries, Environmental Forum http://www.ek.fi/ ymparistofoorumi/fi/tietoa_alasta/suomi_ymparistoliiketoim.php visited 15.1.2012

CPS (2008): Revised European Strategy for Environmental Accounting Theme 5.03, 68TH meeting of the Statistical Programme Committee, Luxembourg, CPS 2008/ 68/7/EN, http://epp.eurostat.ec.europa.eu/portal/page/portal/environmental_ accounts/documents/ESEA_REVISION_2008_0.pdf

Damvad (2011): Fremskrivning af behovet for ingeniører og scienter i fremtiden. Ingeniørforeningen, IDA.

Danish Energy Agency (2011): Predictions - Tables on the Energy predictions of Denmark http://www.ens.dk/da-DK/Info/TalOgKort/Fremskrivninger/ Fremskrivninger/Sider/Forside.aspx (accessed 12. January 2012).

Danish Ministry of Finance (2007): Mod nye mål - Danmark 2015. Teknisk baggrundsrapport.

Danish Ministry of Finance (2011): Personal communication

Eberhardson. M. and A. Wadeskog (2010): Environmental Goods and Service Sector in Sweden - supliers. Statistiska centralbyrån (Statistics Sweden) \& Eurostat.

Econ Pöyry (2009): Grønn økonomi Norge (Green economy Norway). Report 2009004, Econ Pöyry, Oslo.

Efling graens hagkerfis a Islandi (2011): Sjálfbær hagsæld - samfélag til fyrirmyndar, Skýrsla nefndar Alpingis um eflingu græns hagkerfis, Alpingi, September 2011.

European Centre for the Development of Vocational Training (2010): Skills for green jobs, CEDEFOP, Briefing Note.

Eurostat (2009): The environmental goods and services sector, Eurostat methodologies and working papers, http://epp.eurostat.ec.europa.eu/cache/ITY_OFFPUB/ KS-RA-09-012/EN/KS-RA-09-012-EN.PDF 
FORA (2005): Kompetenceklynger - fremtidens vækstmotorer.

www.innovationsraadet.dk

FORA (2006): Miljøteknologiske styrkepositioner. En erhvervsanalyse af klyngedannelse. Miljøprojekt Nr. 1089.

FORA (2009): Kortlægning af miljøteknologiske virksomheder i Danmark.

Government Institute for Economic Research, VATT (2010): Työvoiman tarve Suomen taloudessa vuosina 2010-2025 (Needs for workforce in the Finnish Economy 2010-2025). Tutkimukset 154.

Grünfeld, L.A. and A. Espelien (2011): En kunnskapsbasert fornybar energi- og miljønæring (A knowledge based renewable energy and environmental sector). Menon, Oslo.

Gunnarsson, H. and P. M. Porgeirsdóttir (2011): The Icelandic Geothermal Cluster; Mapping and Mobilization.

Hanhijoki, I., J. Katajisto, M. Kimari and H. Savioja (2009): Education, training and demand for labour in Finland by 2020, Finnish National Board of Education.

Hanley N. and E. Barbier (2009): Pricing Nature: Cost-Benefit Analysis and Environmental Policy. Edward Elgar Publishing.

Heide, K. M., E. Holmøy, L. Lerskau and I. F. Solli (2004): Macroeconomic Properties of the Norwegian Applied General Equilibrium Model MSG6, Reports 2004/18, Statistics Norway.

Industriens Uddannelser (2009): Analyse af vindmølleindustriens kompetencebehov på faglært niveau. Undervisningsministeriet centrale analyse- og prognose virksomhed.

Industriens Uddannelser (2010): Analyse af vindmølleindustriens kompetencebehov på faglært niveau. Hovedrapport.

Ingeniørforeningen, IDA (2011): Prognose for mangel på ingeniører og scient.er. Fremskrivning af udbud og efterspørgsel efter ingeniører og scient.er frem mod 2020.Jensen, A. (2010): Evaluering af vejstøjsstrategien, hovedrapport (Evaluation of the roadnoise strategy). Miljøministeriet (Danish EPA).

Ministry of Economic Affairs (2011): Iceland. Pre-Accession Economic Programme 2011.

Ministry of Environment (2011): Næringsutvikling og grønn vekst (Business development and green growth). The Norwegian Ministry of trade and commerce and the Norwegian Ministry of environment.

Ministry of Science Technology and Innovation (2009): Green research - Status and Perspectives. www.vtu.dk

Muro, M., J. Rothwell and D. Saha (2011): Sizing the clean economy. A national and regional green jobs assessment, The Brooking Institution, Metropolitan Policy Program.

Norwegian Ministry of Finance (2009): Perspektivmeldingen 2009 (The perspective report 2009), Report to the Storting no. 9(2008-2009), Oslo.

OECD (2011): Towards green growth - Monitoring progress, OECD Indicators, C/MIN(2011)5/FINAL, http://www.oecd.org/dataoecd/37/33/48224574.pdf

Pearce, D. W. and R. K. Turner, 1990. Economics of natural resources and the environment, Harverster Wheatsheaf, Ashford colour Press Ltd, Gosport, Hampshire.

Pokela, P., P. Luoma, E. Ryynänen and E. Virtanen (2011): Insinöörien ilmastoohjelman päivitys, Loppuraportti, Gaia Consulting Oy.

Pöyry (2010): Grønne forretningsmuligheter (Green business opportunities), Pöyry report 2010-050, Oslo.

Pöyry (2011): Grønn økonomi i Norge - hva er det og hvordan få det til? (Green sectors in Norway - what is it an how to make it?), Pöyry report 2011-062, Oslo. 
Regeringen (2011): Energistrategi 2050 - fra kul, olie og gas til grøn energi. Februar 2011.

Smith, T. (2008): Statistikk for miljøteknologi, case: vann- og avløpsteknologi (Statistics for environmental technologies, case: water and sewage technologies), Notat 2008/61, Statistics Norway, Oslo.

SOU (2008): The Long-Term Survey 2008. SOU 2008:105, Stockholm.

SOU (2011): Långtidsutredningen 2011, Huvudbetänkande (Long-Term Survey 2011, Main Report). SOU 2011:11, Stockholm

The Committee of Experts on Environmental Economic Accounting (2012): Revision of the system of environmental-economic accounting /SEEA), Note Prepared by the Committee of Experts on Environmental Economic Accounting February 2012.

The World Bank (2012): Green Growth Report, Office of the Chief Economics, Sustainable Development Network IDA/SecM2012-0062.

Tängden, L., U. Johansson, M. Nyman and P. Fränngard (2000): The Environment Industry in Sweden, 2000. Eurostat Working Papers 2/2000/B/10.

UN (2011): Revision of the system of environmental-economic accounts (SEEA), Draft version for Second Round of Global Consultations, United Nations October 2011.

UNEP (2008a): Background paper on green jobs, United Nations Environment Programme.

UNEP (2008b): Green jobs: towards decent work in a sustainable, low-carbon worlds, United Nations Environment Programme.

Vesialan osaaja 2025 (2011): Finnish Water Forum.

Viitamo, E. and H. Hernesniemi (2006): Definition and statistical monitoring of environmental industry - Increased Competitiveness for the Environmental Sector.

Helsinki, ETLA, The Research Institute of the Finnish Economy, Discussion Papers, ISSN 0781-6847; no. 1019.

Vækstfonden (2008): ABC til internationalisering og vækst - perspektiver for venturekapital til danske cleantech-virksomheder.

Økonomi- og Erhvervsministeriet (2008): Baggrundsrapport om danske styrkepositioner på klimaområdet. 



\section{Sammendrag}

Når man forsøker å samle noen aktiviteter i en «grønn» gruppe, definerer man samtidig aktivitetene utenfor gruppen som ikke-grønne. Vi konkluderer med at det ikke er mulig å lage konsistente prinsipper for å separere grønne aktiviteter fra resten av økonomien. Grunnen er at alle aktiviteter medfører press på miljøet på en eller annen måte, og er således mer eller mindre grønne, eller relativt mer eller mindre miljøskadelige.

Det i dag viktigste initiativet for å måle grønne sektorer er FN/Eurostats initiativ EGSS (Environmental goods and services sector). Dette rammeverket er ment å danne en internasjonal standard, og omfatter de aktiviteter som har miljømessig hensikt («purpose») som hovedformål. Her inkluderes for eksempel fornybar energiproduksjon og gjenvinning av avfall. Imidlertid vil alle aktivitetene være mer eller mindre grønne, og fornybar energi er et godt eksempel. Vannkraft, vindkraft og biodrivstoff medfører blant annet demninger, metanutslipp, veier og konstruksjoner i naturområder og karbonutslipp fra avskoging. Gasskraft, som ikke anses som grønt, medfører utslipp av klimagasser, men kan bidra til reduserte utslipp dersom alternativet er kullkraft. Ved å konstruere to kategorier, verdsettes implisitt kostnadene ved ene typen energiproduksjon som lavere enn en annen, uten at denne verdsettingen er eksplisitt formulert og utsatt for vitenskapelige vurderinger.

I prinsippet har ingen aktiviteter miljø som hovedformål, slik utgangspunktet er for FN/Eurostat. Hovedformålet med vannkraftproduksjon er å maksimere den økonomiske verdien av vannressursene, og hovedformålet for gjenvinningsindustiens eiere er å maksimere profitten. Samtidig er forbrukerne avhengig av energi- og avfallstjenester. Produksjon, konsum, sysselsetting og miljøskader og andre kostnader balanserer i et samspill i stadig forandring. Noen aktiviteter medfører større utslipp per produsert enhet og per sysselsatt enn andre. Men siden de ulike aktivitetene i økonomien er avhengig av hverandre, er det ikke mulig å tilskrive miljøkostnadene til enkelte aktiviteter, mens andre betraktes som grønne.

I mangel av prinsipielt grunnlag, blir definisjonene av grønne statistikker vilkårlige og subjektive. Vi konkluderer med at statistikker over grønne sektorer, som EGSS, er basert på lav statistisk kvalitet. 
Initiativene synes å være drevet av ønske om å følge miljøutviklingen for ulike bransjer, sektorer eller økonomien som hele, og å sammenligne mellom land. Miljømyndigheter og politikere ønsker informasjon for å demonstrere effekter av miljøpolitikk, og land med høy arbeidsledighet ser etter nye næringsveier og muligheter for økonomisk vekst.

Eksisterende miljøregnskaper og nasjonalregnskaper dekker allerede statistikker som kan dekke disse informasjonsbehovene. Disse statistikkene gir transparente og detaljerte tall for utslipp, produksjon og sysselsetting på detaljerte sektornivå, og kan for eksempel vise miljøbelastning per produsert enhet og per sysselsatt. Slike statistikker taler for seg selv, og det er ikke nødvendig å gjøre subjektive valg av hvilke sektorer som skal være innenfor og utenfor statistikkene. Videre er økonometriske analyser basert på samme typen data veien å gå for å analysere effekter av politiske virkemidler. Framskrivninger av makroøkonomiske modeller gir de beste antydningene over hvilke typer sektorer som vil vokse i framtiden, under ulike forutsetninger om miljøpolitikk, og over hvilken type kompetanse som man kan vente behov for. 
Ved Stranden 18

DK-1061 Copenhagen K

www.norden.org

\section{Measuring green jobs?}

An evaluation of definitions and statistics for green activities

The report reviews the different initiatives aiming to measure aspects of "green" sectors, jobs and technologies. The report discusses whether the statistics collected under the present initiatives aimed at measuring these aspects increase insights into the fundamental questions motivating the initiatives. An alternative framework is suggested, as it appears fundamentally impossible to make consistent frameworks for a division of the economy into "green" and "non-green" activities.

The analysis has been carried out during the period September 2011 March 2012 by Vista Analysis AS, Gaia Consulting Oy and University of Aarhus. Gaia Consulting Oy is responsible for the chapters 5.2., 5.3, 6.2, 6.3 and 7.2 only. The project was commissioned by the Working Group on Environment and Economy under the Nordic Council of Ministers. 